\title{
Estudio del Ager Aesonensis (Isona i Conca Dellà, Pallars Jussà, Lleida)
}

\author{
Teresa Reyes i Bellmunt * \\ Ricardo González Villaescusa *** \\ Joan Eusebi Garcia i Biosca
}

\begin{abstract}
RESUMEN
La prospección sistemática de una muestra del territorio de la ciudad ibérica y romana de Eso/Aeso permitió descubrir la existencia de una red relativamente densa de núcleos rurales en las inmediaciones de la ciudad.

Se realizó un análisis morfométrico del parcelario de la zona, detectándose, junto a operaciones de época medieval y moderna, al menos dos (re)ordenaciones del paisaje rural adscribibles a época antigua: vestigios de un parcelario centuriado, y un sistema parcelario coherente -sus estructuras mantienen una orientación coherente, con cierto ritmo métrico, aunque sin la rigurosa ortogonalidad de una centuriación.

Se pusieron en relación los datos de la prospección sistemática con los de la fotointerpretación, mediante un SIG. Cruzando dichos datos con variables ambientales, se confirmaron y plantearon hipótesis sobre la cronología y funcionalidad de los parcelarios antiguos.
\end{abstract}

PALABRAS CLAVE: Aeso, prospección, parcelario, sistema coherente, indígena, centuriación, Sistema de Información Geográfica (SIG).

\section{CONSIDERACIONES PREVIAS}

El planteamiento de este estudio ha sido complementario al ya iniciado hace unos años a nivel de trabajo de campo y dirigido por Teresa Reyes i Bellmunt. Lo que se ha estado realizando es un estudio del parcelario mediante fotografías aéreas y las trazas que éstas nos

\begin{abstract}
A systematic prospection survey in the territory of iberan and roman town of Eso/Aeso allowed the discovering of a relatively dense net of rural settlements. We proceed to analyse morphometrically the landscape. Apart from some medieval and modem age interventions, we found at least two kinds of ancient age (re)ordinations of rural landscape.

Besides the relics of a centuriated parcellation, we found traces of a coherent parcellation system, in which structures keep a coherent orientation and follow some kind of metrical rhythm in spite of lacking the rigorous orthogonallity of a centuriation.

At last, the data acquired during systematic prospection and those obtained by photointerpretation were merged using a GIS. Some environmental variables were crossed with the former data to confirm hypothesis a suggest new ones relative to chronology and functionality of both ancient parcellation.
\end{abstract}

KEY WORDS: Aeso, prospection, coherent system, indigenous, centuriatis, Geographic Information System (GIS).

permiten ver de la ocupación del territorio a lo largo del tiempo.

En una fase posterior y, para acabar los objetivos que nos habíamos fijado al inicio de este trabajo, hacia falta hacer la comprobación directa sobre el campo para verificar lo que hasta el momento se ha interpretado.

* Museo de la Conca Dellà. * *** Doctor en Arqueología. Universidad de Valencia. 
En esta fase se han incorporado al equipo dos personas, Ricardo González Villaescusa, miembro asociado del CNRS-UMR 6575 Archéologie et Territoires, especialista dedicado a análisis morfológicos por cartografía y fotointerpretación del territorio; y Joan Eusebi Garcia i Biosca, uno de los miembros activos en los trabajos de prospección de campo realizados en un primer momento y encargado de hacer el análisis del estudio mediante un sistema de información geográfica (SIG).

La documentación utilizada para el análisis morfológico ha sido la fotografía aérea correspondiente a Isona y su territorio más inmediato (vuelo americano, fotograma $n^{\circ} 12.258$, 19/07/ 56); el plano a escala 1:25.000 (hoja 5V, 62-63 Isona 290); el plano de parcelario a escala 1:5.000 de la zona que rodea a la ciudad; y finalmente, un parcelario urbano de Isona a una escala aproximada de 1:1.939 en formato DIN-A3).

La documentación arqueológica que hay sobre la zona también ha sido utilizada, así habría que nombrar a nivel específico sobre la ciudad los trabajos realizados por el Equipo PRAMA (PAYÀ, PUIG I REYES: "Primeres datacions del nivells fundacionals d'Aeso" en la Revista d'Arqueologia de Ponent, $n^{\circ} 4$, Lleida 1994) y a nivel de trabajos de prospección y estudio del territorio, la base del trabajo ha sido la tesis de licenciatura presentada en el año 199| intitulada "Aproximació al poblament romà a les rodalies d'Aeso: un assaig metodològic" realizada por T. Reyes. También se ha utilizado la carta arqueológica de la comarca del Pallars Jussà realizada por el Servicio de Arqueo-logía de la Generalitat de Catalunya el año 1994.

En términos más generales y de tipo jurídico y administrativo han sido fundamentales las numerosas referencias a Aeso del trabajo de J. Pons, "Territori i societat romana a Catalunya. Dels inicis al Baix Imperi", Barcelona 1994.

A nivel económico este último estudio ha sido posible gracias a una ayuda CIRIT (Comissionat per a Universitats i Recerca, dependiente del Departamento de Presidencia de la Gene- ralitat de Catalunya) para el desarrollo de proyectos de investigación de alcance comarcal (ACOM) concedida al Museu de la Conca Dellà el año 1995.

\section{MARCO GEOGRÁFICO}

La villa de Isona, cabeza del actual municipio de Isona i Conca Dellà, esta situada al suroeste de la comarca del Pallars Jussà en la provincia de Lleida. Actualmente, es una pequeña población de 650 habitantes, que constituye el centro, tanto físico como económico y de comunicaciones, de la zona que le rodea. Isona se encuentra a $663 \mathrm{~m}$ de altura sobre el nivel del mar (coordenadas UTM 3 ITCG38436485), en un lugar llano, ocupando un extremo meridional de un contrafuerte bajo situado al pie de la sierra por donde discurre la carretera de Isona a Coll de Nargó, por Bóixols (mapas escala 1:50.000 de la Dirección General del Instituto Geográfico y Catastral, hoja 290, año 1950, série L escala 1:50.000 Servicio Geográfico del Ejército, hoja 33-12, año 1959).

La forma de su núcleo urbano recuerda un triangulo alargado en dirección NE-SO, atravesado por la carretera C-1412, de Artesa de Segre a Tremp. El área sobre la que se desarrolla fundamentalmente el estudio que se presenta es, precisamente, la zona conocida como la Conca Dellà, en tanto que espacio físico circundante de la antigua ciudad de Aeso, la actual Isona.

Este territorio esta limitado por todas partes, excepto por una, por una serie de sierras que la encierran formando un valle casi cerrado. Así, pues, al oeste nos encontramos con la única "frontera" abierta, el río Noguera Pallaresa, al este la sierra de Comiols, al norte las sierras de Sant Corneli, Carreu y de Bóixols, y al sur las carenas de la sierra del Montsec. La Conca esta atravesada de este a oeste por el río Gavet o río de Conques, afluente del Noguera, y por el río Abella, también tributario del anterior, así como por diferentes riachuelos y torrentes que tejen un denso entrelazado por toda la zona (Fig. I I). 
La situación de la Conca Dellà, con una altura mediana de $500 \mathrm{~m}$ sobre el nivel del mar y rodeada completamente por sierras que superan los $1.000 \mathrm{~m}$ de altura, crea un microclima especial, que, juntamente con la fertilidad de sus tierras, permite el desarrollo de una vegetación y agricultura más propia de territorios mediterráneos o meridionales que no pirenaicos que corresponderían debido a la latitud en la que nos encontramos.

Los cultivos ocupan la mayoría de las tierras llanas del termino, quedando las cimas de las sierras como bosques y matorrales aprovechadas por el ganado. La mecanización de los campos ha permitido una utilización intensiva de los cultivos, predominando sobre todo los cereales y los almendros. Complementariamente se ha desarrollado una creciente ganadería, sobre todo porcina y ovina; bovina en menor medida.

\section{REFLEXIONES EN TORNO A LOS TRABAJOS DE CAMPO REALIZADOS ANTERIORMENTE}

El inicio de las investigaciones arqueológicas en el antiguo municipio romano de Aeso incidía en la necesidad de hacer un estudio exhaustivo de su ámbito más inmediato. Era conveniente, al menos para un buen principio, poder hacer un examen riguroso de toda la superficie objeto de estudio, y ya en un momento más avanzado poder intensificar los esfuerzos teniendo en cuenta, eso sí, que se partía con ciertas desventajas: una orografía dificultosa y las limitaciones inherentes a una o dos personas, que harían limitar la atención hacia aquellos lugares en los cuales la presencia de ciertos indicios nos hiciera verosímil la identificación como lugares de hábitat o de desarrollo de cualquier actividad andrógena, o también en lugares determinados previamente y reconocidos por otros medios, intentando responder, así, a algunas de las cuestiones clave que llevaran a la elección del lugar para un asentamiento urbano importante.

Para poder alcanzar estos objetivos se impone llevar a termino una investigación sobre el terreno a la vez que sobre todo tipo de fuen- tes que puedan ofrecer información alrededor de las formas de uso y ocupación del territorio generados por este sistema, el centro del cual radica en el municipium aesonensis.

En un momento más avanzado de la investigación, los fines perseguidos son de doble naturaleza, metodológica e histórica, aunque, debido al estado en que se encuentra la investigación, parece más fácil obtener resultados inmediatos en el primero de los campos que en el segundo.

Las propuestas metodológicas sobre las que se han apoyado, tanto el trabajo de campo como la posterior elaboración de los datos obtenidos, buscan superar las dificultades ofrecidas por los métodos tradicionales de prospección y desarrollar un sistema de recogida y registro de datos que favorezca la integración de estos dentro de los esquemas de una arqueología no necesariamente nueva. Esta habría de intentar huir del estricto marco impuesto por la excavación y volverse un instrumento útil para la comprensión de la creación y modificación de paisajes humanizados ("landscapes") y que los datos, lejos de ser el centro y objetivo de todo el proceso de investigación, sean concebidos como un elemento que va hacia la obtención de supuestos interpretativos obtenidos mediante la comparación de resultados obtenidos gracias a medidas, más o menos precisas, integradas dentro de un sistema teórico.

Se pretende desarrollar un sistema de recogida y gestión de datos, evidentemente innovador, apoyado en experiencias que se están llevando a cabo entre nosotros y más allá de nuestras fronteras, que permita la comparación de resultados obtenidos en diferentes lugares del área de estudio. Las diversas variables no determinadas que influyen en el comportamiento y la calidad de los datos obtenidos (calidad del equipo de prospección, estado del terreno, luminosidad, grado de visibilidad del material sobre la superficie,...) han de ser tenidos en cuenta, así como ha de ser evaluada su influencia relativa mediante procesos de experimentación y así poder equiparar los resultados obtenidos en diferentes áreas, por diferentes investigadores y bajo condiciones diversas. 
Si hablamos de la manipulación de la información, esta estará sujeta a un serie de parámetros que nos condicionaran el uso que se haga con posterioridad. Así, todo el material de cada una de las fases históricas tomadas en consideración habrá de ir acompañado por datos sobre las condiciones en que se recogieron, ubicación topográfica, atribución cultural y cronológica, representatividad dentro de un área, presencia porcentual... Todos estos elementos habrán de servir de vía a través de la cual integrarse en los diferentes análisis que, partiendo de estas fases, se puedan llevar a término.

Todo este corpus de elementos dotados de dimensión cultural y cronológica, espacial y cuantitativa se habrá de interrelacionar con la evaluación del medio geomorfológico, paisajístico... así como con la propia distribución de estos elementos en el espacio para averiguar cuáles son las causas que hacen que el registro arqueológico adopte una configuración y no otra.

Los interrogantes históricos que nos planteamos se centran en la influencia que los cambios sociales y políticos vividos en la zona entre la época en que se hizo efectiva la presencia romana hasta el derrumbe de las formas de vida generadas por la cultura latina y su sustitución por otras ya medievales y caracterizables como feudales. El aspecto en torno al que se centrará nuestra atención será el poblamiento, los diferentes patrones y las tipologías de este dentro de un proceso diacrónico que abarca el lapso de tiempo antes mencionado.

Un elemento clave para entender la evolución de las formas de asentamiento romanas y su interrelación es el conocimiento de aquellas que les precedieron y de las que fueron herederas. El poblamiento ibérico es, sin ningún tipo de duda, uno de los más conspicuos desconocidos de la incipiente arqueología pirenaica. Excepto algunas noticias de los autores clásicos sobre los exóticos pueblos que habitaban estas tierras durante los primeros siglos de presencia romana en la Península, la arqueología no ha ofrecido datos que dieran una luz excesivamente esclarecedora sobre la problemática de estudio que estos comportan.
La comprensión de los patrones de asentamiento, la tipología y funcionalidad del hábitat indígena inmediatamente anterior a la llegada del influjo romano ayudaría a establecer hasta qué punto éste actuó como elemento aculturador $y$ anihilador del substrato preexistente. Tendría también que determinar, si fuera posible, la existencia o no de contactos con el comercio griego o romano, previamente a la inclusión del área dentro de la férula del Imperio y de que manera, en caso de haber existido, constituyeron un primer peldaño dentro del proceso de desestructuración de la sociedad ibérica de la zona. En última instancia, pero no menos importante, haría falta investigar de qué forma la entrada dentro del circulo de obligaciones-derechos inherentes al establecimiento del dominio romano y, especialmente, las cargas que este imponía a los pueblos sometidos (tributación, quinta,...) se traducen en el registro arqueológico mediante la opción por unos tipos de cultivo fácilmente monopolizables y de almacenamiento fácil, la entrada dentro del sistema monetario latino...

En referencia al período en que se consolida y crece el sistema económico y de poblamiento romano, haría falta proceder, como en época ibérica tardía, a determinar la tipología de asentamientos mediante los cuales se llevara a término la "urbanización" del ager, precedida por la fundación de Aeso. La funcionalidad de las diferentes formas de hábitat nos hablará del papel desarrollado, por los grupos de población que los ocupan, en la explotación del espacio agrícola y ganadero, suministrando datos sobre el equilibrio entre las dos formas de economía y el grado de autarquía o relación con los mercados exteriores. El equilibrio entre grande y pequeña propiedad constituye otro de los puntos clave en esta investigación, fundamentalmente para definir la auténtica influencia de una ciudad altamente oligárquica sobre su entorno.

El análisis de la presumible etapa de crisis del bajo Imperio esta presidida por dos interrogantes: ¿cuándo? y ipor qué? Considerando, a partir de los datos ofrecidos por las campañas de excavación llevadas a término en la ciudad y por lo que se empieza a conocer sobre el 
poblamiento rural, que tanto el hábitat urbano como el rural parecen retraerse hacía posiciones elevadas, dentro de una tónica generalizada de abandono del llano a favor de las laderas montañosas, sería tentador considerar este fenómeno como una vuelta a la fase anterior a la presencia romana, como un restablecimiento de las formas "naturales" de ocupación del espacio, pero no se puede omitir los condicionantes propios de cada etapa de la historia y la carga que suponen los restos del pasado.

Al no haber conseguido, aún, resolver satisfactoriamente los interrogantes que plantea la relación entre el registro arqueológico ofrecido por las prospecciones y las pautas culturales de comportamiento que lo generan, resulta difícil y arriesgado emitir opiniones sobre si determinada concentración obedece a la existencia de una villa o si sólo representa un foco de actividad extraresidencial. La influencia de las variables propias del proceso de recuperación así como la trayectoria postdeposicional de los ítems con los que trabajamos están muy lejos de estar correctamente evaluados $y$, en consecuencia, el filtrado de los datos "en sucio" se hace extremadamente impreciso.

La limitación del área cubierta así como el estado de incipiente desarrollo de los métodos e ideas empleadas obligan a presentar conclusiones forzosamente limitadas sobre los aspectos que centran este estudio, el poblamiento romano de la Conca Dellà y las mutaciones que este sufre desde que surgió como fruto de una decisión política romana hasta que, una vez periclitada esta última, se abre la vía hacía la sociedad feudal.

Si nos atenemos a la dispersión de las diferentes producciones cerámicas en toda la superficie prospectada podemos deducir determinados datos de interés para comprender la evolución del poblamiento y las formas de ocupación del espacio de las cuales son evidencia. Éstas, combinadas con la información que ofrece el entorno donde se localizan, aportan una luz considerable sobre las opciones tomadas por los habitantes de la zona en época romana a la hora de explotar determinadas áreas, etc.
También hemos de hacer una observación de importancia para poder comprender mejor la estructuración del poblamiento: su relación con una red viaria antigua que empieza a delinearse contextualizando los yacimientos o localizaciones inventariados con los ejes de comunicación de largo recorrido que aún hoy perduran en las tierras llanas del fondo de la Cuenca, aunque muchos de ellos en franco proceso de recesión.

En conclusión, las prospecciones llevadas a término en el ager aseonensis, nos llevan a pensar que el momento clave de creación del sistema del poblamiento que impera en esta zona durante la época de domino político romano fue la etapa ibérica tardía/republicana, momento en el que se crea la ciudad como tal y empiezan a surgir los primeros asentamientos de llano ya alineados con los ejes viarios mencionados. En este mismo momento deben desaparecer algunos de los asentamientos indígenas de ladera. Con la época del alto Imperio asistimos a la densificación de la red de poblamiento que se había conocido incipientemente durante el período anterior, densificación que avanza en dos direcciones: hacia el relleno de espacios intersticiales entre yacimientos de rango medio con localizaciones de dimensión pequeña y hacía la creación de núcleos de grandes dimensiones. Con la llegada de las crisis bajo-imperiales, hacía el siglo III, la información empieza a faltar en los pequeños núcleos aparecidos durante el período anterior, incluso en la ciudad o en los núcleos de rango elevado este material representa un porcentaje francamente pobre en comparación con los volúmenes atribuibles a períodos precedentes.

Los datos con los que se cuenta hasta el momento, aunque escasos, están en condición de integrarse con futuras aportaciones extraídas de nuevas campañas de investigación de campo para así poder generar conocimiento sobre la ciudad de Aeso y las tierras que ocupan la actual comarca del Pallars Jussà.

Para acabar, y como ya se ha dicho, la recogida de material era exhaustiva, pudiéndose constatar yacimientos pertenecientes a perío- 
dos diferentes a los que ocupa nuestro estudio. Así pues, se pueden destacar concentraciones de materiales tanto de época prehistórica como medieval en algunas de las cuadrículas prospectadas. También hay que decir que en toda la zona estudiada se han situado restos muebles pertenecientes al período moderno, los cuales no se han analizado, pero quedan reflejados con la posibilidad de poder incluirlos en estudios posteriores de la zona y que ocupen este período.

\section{OCUPACIÓN DEL SUELO Y ESTRUCTURAS AGRARIAS DEL AGER AESONENSIS}

\section{IV.I.Análisis de las formas del paisaje rural de la ciudad íbero-romana de Eso-Aeso (Isona-Lleida)}

La documentación utilizada para el análisis morfológico ha sido la fotografía aérea correspondiente a Isona y su territorio inmediato -fotograma $n^{\circ} 12.218$ del denominado vuelo americano, fecha 19/07/56-; los planos cartográficos a escala l:25.000, hojas de Isona, Ortoneda, Guardia de Tremp y Tremp. Los planos parcelarios a escala 1:5.000 de las inmediaciones de la ciudad; $y$, finalmente, un parcelario urbano de Isona a escala aproximada I:I.939.

La investigación de las manifestaciones parcelarias del territorio de Aeso ha sido llevada a cabo en diferentes niveles. En el primer nivel, tendente a definir la extensión máxima del parcelario centuriado, se realizó la cartointerpretación del montaje de cuatro planos a escala 1:25.000 que abarcaban la totalidad de la Conca Dellà: hojas de Tremp, Ortoneda, Guardia de Tremp e Isona (Fig. I I). El segundo nivel de observación consistió en la fotointerpretación del espacio limitado a las inmediaciones de la ciudad, que incluye las cuadrículas prospectadas sistemáticamente en los años 1989 y 1991. Esta zona coincide con el fotograma ya citado, delimitado por los río de Abella y de Conques (norte y sur respectivamente) y las Serra de Carreu, Serra de la Conca, Roc de Benavent y Serra de Comiols (Figs. 12, I5). El tercer nivel de aproximación, supuso la cartointerpretación de detalle sobre el plano 1:5.000, coincidiendo con las hojas de St. Romà d'Abella, Isona y Can Moreres, que corresponden al sector más occidental de la cuadrícula descrita.

Por otra parte, como consecuencia de las características morfológicas de un sistema coherente, no hemos podido llevar a cabo el análisis al nivel espacial más amplio que hemos alcanzado con el sistema centuriado. La adaptación constante de sus líneas básicas a las principales orientaciones de la morfología estructural podrían llevarnos a extender su radio de acción a cualquier medio geográfico si excluíamos el factor ocupación del suelo. Las prospecciones sistemáticas realizadas en las inmediaciones de Isona y la calidad de la fotointerpretación de detalle en el mismo sector, suponen una mayor densidad de observaciones arqueológicas y morfológicas, que permiten contrastar mejor las hipótesis, y nos han aconsejado limitarnos al segundo nivel.

\section{IV.2. Estructuras agrarias de la Conca de Isona}

Las estructuras agrarias y viarias de la Conca de Isona se organizan en torno a dos orientaciones fundamentales en las que se insertan los yacimientos y elementos del paisaje de época antigua confirmando la antigüedad de esos trazados. Aunque ambas orientaciones y su antigüedad ya fueron propuestas a grandes rasgos (REYES 1991, 51), los trabajos de arqueomorfología y fotointerpretación han permitido formalizar y definir sus características e impronta en el paisaje.

\section{A. Un sistema parcelario coherente}

La orientación predominante de la Conca de Isona coincide con la orientación estructural de la misma, concretamente de los depósitos cuaternarios, glacis plio-cuaternarios, (PEÑA 1983 , 227). Los torrentes subsidiarios del río de Conques -barrancos de la Boïga, Solans, Francolí y arroyo de la Colomera- se adaptan a esta orientación, encajándose y excavando los depósitos cuaternarios. Pero, además de los torrentes, la 
mayoría de los paleocauces - revelados por las marcas de humedad remanente en el suelo o damp-marks- coinciden con la orientación o se adaptan a las líneas del sistema general, cumpliendo la función de afluentes.

La fotointerpretación del sector (Fig. 13) o la simple observación del plano topográfico, ponen en evidencia la orientación dominante del viario que se adapta a esa pendiente natural: la carretera entre Conques y Sant. Romà de Abella -longitud máxima del eje: 2'3 km-, y la carretera de Isona a Abella $-6 \mathrm{~km}-$, siguen la misma orientación, oscilando entre NG-33 ${ }^{\circ}$ E y NG-45 E, y condicionando los parcelarios asociados.

La morfología general es la propia de lo que se conviene en llamar sistema coherente, típico de los parcelarios protohistóricos (BRADLEY, RICHARDS 1978, CHOUQUER 1996). Se trata de estructuras que mantienen una coherencia de orientación aunque sin la rigurosa ortogonalidad de una centuriación. El trazado de los ejes principales y secundarios reproducen el concepto que hemos aplicado a los parcelarios de regadío: la regularidad orgánica (GONZÁLEZ VILLAESCUSA 1996a, 159), donde ejes y límites secundarios siguen la sinuosidad condicionada por una exigencia topográfica natural, adaptándose a ella, aunque intentando guardar un ritmo métrico.

En efecto, si nos apoyamos en la orientación media -NG-38 $\mathrm{E}-$ y en los dos ejes principales obtenemos un número significativo de coincidencias, menor en los ejes transversales, poniendo en evidencia un ritmo metrológico reiterativo. La distancia entre los dos ejes principales es de 1.575 m, múltiplo (×3) de 525 m, que también lo vemos materializarse en distintos sitios. Se trata de la misma distancia que se repite en sistema coherente de la ciudad ibérica de Edeta, 525 m (GONZÁLEZZ VILLAESCUSA 2000 y en prensa).

Si comparamos esta estructura con la dispersión del poblamiento en torno a la antigua Aeso se comprueba cómo los ejes, principales y secundarios, se encuentran jalonados por asentamientos tardorrepublicanos y altoimpe- riales. Así el Tossal de la Collada-Tosca de Pauet - cuya proximidad hace pensar que se trata del mismo asentamiento-, flanquean el eje Conques-St. Romà, mientras que la villa del cementerio de St. Romà, se encuentra en el extremo noreste del mismo. En el eje Isona-Abella y su prolongación hacia el suroeste se encuentran la Granja del Portal, la misma ciudad, els Horts o la Serreta, finalizando, por el suroeste, en una cantera explotada desde antiguo. Fuera del área estudiada en profundidad, y en la proximidad del mismo eje, también se encuentra el asentamiento altoimperial de Ferginals Isona-Abella. Por otra parte, los asentamientos de Els Prats y de la Casa de la Borda, también se encuentra en la proximidad de algunos ejes, la primera en un cruce, la segunda en otro eje más largo, que bordea el río de Conques.

Sin embargo, no todos los asentamientos organizan parcelario isoclino, es decir, no se encuentran en el interior de amplias superficies de parcelario coherente: sólamente el Tossal de la Collada, els Horts (tardorrepublicano), la Serreta (tardorrepublicano), els Prats (altoimperial), la Granja del Portal (altoimperial), o la Casa de la Borda (altoimperial). La presencia de asentamientos de cronología altoimperial permite concluir que el sistema parcelario estructura el espacio rural durante toda la Antigüedad, como aún lo hace hoy en día, y del que el parcelario centuriado no hizo tabula rasa. Quizá sea más significativa la comparación de los asentamientos con el parcelario centuriado.

Aunque la orientación del recinto de la Aeso tardorrepublicana es próxima a la del parcelario coherente, la coincidencia debe ser minimizada porque tanto la muralla como la propia estructura parcelaria, se encuentran condicionadas por el relieve, como el mismo altozano sobre el que se halla Isona. En este sentido, es más significativo el hecho de que el principal itinerario del sistema "atraviese" la ciudad.

Todos estos datos permiten poner esta estructura en relación con un sistema parcelario coherente que, de manera muy genérica, sería prerromano; las semejanzas formales, 
metrológica o funcionales que mantiene con el identificado en Edeta-Llíria (GONZÁLEZ VILLAESCUSA 2000), o con el formalizado en les Costières -Nîmes- (GONZÁLEZ VILLAESCUSA 1997) redunda en la misma identificación.

\section{B. Un parcelario centuriado de $15 x \mid 5$ actus}

No utilizamos expresamente el término centuriación, que reservamos a intervenciones coloniales fuertes asociadas a deducciones de veteranos, y preferimos la perífrasis de "parcelario centuriado" pues refleja mejor una organización de los campos a la romana, sobre la que nos extenderemos más adelante.

La existencia de una serie significativa de límites orientados a NG-28 $30^{\prime} \mathrm{W}$, que organizan amplias superficies del territorio de Aeso, pero que no constituyen el armazón viario principal, más la coherencia de éstos con una retícula de $\mid 5 \times 15$ actus (532'3 m de lado) nos permite plantear la hipótesis de que se trate de un parcelario de carácter limitado de origen antiguo (Figs. II y |2).

La influencia septentrional de sus manifestaciones parcelarias parece encontrarse a los pies de la población de Aramunt, en el lugar de las Eras, hasta St. Martí de Canals, donde se organiza una importante extensión de parcelas orientadas a $28^{\circ} 30^{\prime}$, coincidiendo con la proximidad del que hemos denominado kardo máximo que describiremos más adelante (Fig. I I). No demasiado lejos se encontró una necrópolis (MALUQUER DE MOTES 1947-48, 293-295) que pudo pertenecer a la instalación agrícola que explotaría estas tierras.

La presencia de esta misma orientación de las parcelas más allá de Isona, al otro lado de la Muntanya de St. Corneli ( 1.35 I m s.n.m.), supone un indicio del papel estructurante de este parcelario en época antigua, cuando la influencia de la ciudad de Aeso se extendía a la totalidad de su territorio, asimilable a la actual comarca. Además, la construcción de límites con idéntica orientación más allá de relieves de importancia supone la utilización de técnicas agrimensoras como la cultelación - cultellatio- (FRON-
TINO, De limitibus, La. fig. 26, 33, 19-34, I3), en su interpretación más reciente e innovadora de "medición a la horizontal" (ROTH CONGES 1996, 315328); que contribuyen a la adscripción romana del parcelario.

Su impronta más allá del Noguera Pallaresa, o incluso en la orilla izquierda, es anecdótica, coincidiendo algunas trazas en Salás del Pallars, Talarn, y en las inmediaciones de Tremp. Probablemente sólo se trate de coincidencias y no podamos extenderlo más allá del río que, en ese caso, supondría una frontera natural de la pertica y, quizás del territorio aesonense. Por el noreste y este el límite natural del mismo $y$, al mismo tiempo de la pertica, es el conjunto de sierras formado por la Serra de Carreu, Serra de la Conca, Roc de Benavent y Serra de Comiols, que también constituyen el límite comarcal actual. Finalmente, la Serra de la Campaneta y de la Vall de Llimiana constituyen el limite físico meridional de las tierras de cultivo y, por tanto, de las improntas de límites parcelarios orientados como el parcelario centuriado.

El eje cardinal principal o kardo máximo, si no nominal sí de hecho, por su longitud -l'6 km- e importancia en la gestión de los espacios agrarios, se encuentra en el Pla del Vall (Fig. 12). Es precisamente este tipo de eje, que conserva un buen tramo rectilíneo y no une poblaciones, el que nos sirvió de apoyo para reconstruir el parcelario limitado. Tras desaparecer, hacia el norte, lo volvemos a encontrar, desplazado de su trazado hipotético, al norte de la zona de Els Prats, dando lugar al cruce de caminos - uno de los cuales, fósil y visible en la fotografía aérea- en cuyas inmediaciones se encontraba una ermita desaparecida. Siguiendo su trazado hacia el sur, el barranco de Solans era atravesado por un puente medieval cuyos vestigios se hallan en el trazado hipotético del kardo. Una vez franqueado el barranco, puede seguirse el trazado materializado en el terreno, aunque ausente de la documentación, en forma de vereda para el ganado aún frecuentada. En las proximidades de la ciudad antigua pasa muy próximo al límite del recinto amurallado y más al sur cabe resaltar la proximidad del eje al emplazamiento del 
puente romano de Covet, cuya orientación coincide groseramente (NG-31 ${ }^{\circ} \mathrm{W}$ ) con la del parcelario, si bien, su degradación impide mayores precisiones.

La mejor conservación de límites y de masa parcelaria isoclina la encontramos entre Las Esplugas y Sant Romà, coincidiendo con la dispersión de materiales de la única villa identificada: Cementiri de St. Romà. Numerosos límites parcelarios se adosan perpendicularmente al decumano y compartimentan el espacio de una de las centurias, formando tres bandas de 5 actus cada una, conservando lo que pudo ser la división antigua en unidades de cultivo. La dispersión de materiales de esta villa (REYES 1991, 46) coincide bastante con el parcelario isoclino, encontrándose articulada en torno a un cruce formado por un eje decumano mayor -de una longitud de casi tres centurias: I' $35 \mathrm{~km}-\mathrm{y}$ un pequeño kardo -331 m-.

A su vez, la ermita de St. Pere Màrtir, también se encuentra en un cruce de caminos (REYES 1991, 46) aunque todo parece indicar que se trata de tres caminos pertenecientes a los dos sistemas: el que conduce de la ermita a St. Romà y el que lleva de ésta al cementerio son isoclinos con el parcelario centuriado, mientras que la carretera de Conques a St. Romà se inserta en el sistema coherente. Más interesante es destacar cómo el decumano que organiza el espacio correspondiente a la villa del cementerio de St. Romà, se deforma por "atracción" de este templo. Si la ermita pudo encontrarse originalmente en el eje Conques-St. Romà, el decumano pudo desviarse para encontrar el lugar de culto, tal y como ocurre en los ejemplos italianos analizados por G. Chouquer (1983, 144), formándose la actual encrucijada de distintos sistemas ya en época altomedieval, momento en que deben fecharse los orígenes del templo. Este hecho y su posición intermedia entre el asentamiento antiguo y la actual población pone en evidencia el desplazamiento hacia el oeste que terminaría en el actual solar. Precisamente la población actual se halla en el centro geométrico de una centuria, rodeado por una buena conservación de límites y masa parcelaria coherente.
En efecto, la relación espacial que mantienen todos estos elementos con el parcelario, permite pensar que se trata de algo más que una casualidad. La calidad de los materiales encontrados -mármoles y capitel de pilastray la perduración del asentamiento -desde mediados del siglo I al siglo VI- podrían explicar la permanencia del connotativo topónimo de Sant Romà y la creación de una comunidad aldeana altomedieval a partir de un antiguo e importante fundo que perduraría tras la crisis del siglo III, como ocurre en ejemplos del Languedoc (PARODI 1992, 672).

Sin solución de continuidad y hacia el este se extiende desde les Peixines hasta el barranc de Fonguera una extensa y homogénea superficie, 128 ha $=4,5$ centurias, de parcelario isoclino que de no existir otro asentamiento más, podría redundar en la importancia de la explotación agrícola. Esta dimensión del terrazgo sería coincidente con la propuesta para las más grandes villae del territorio de Vgernvm (Beaucaire) y las del ager cosanus como Settefinestre (BESSAC et alii 1987, I। 0).

Otro de los sectores de fuerte conservación de este parcelario se encuentra al noreste del yacimiento del Tossal de la Collada, entre el Camp d'Abella y els Prats de St. Romà. La relación con el yacimiento es digna de mención ya que se trata de uno de los asentamientos de cronología antigua -ánforas ibéricas, itálicas y Tarraconense- que pudo transformase en un asentamiento de cronología plena altoimperial, por descenso al piedemonte sureste -Tosca del Pauet. Si la creación del parcelario puede ponerse en relación con esta transformación y desplazamiento, sorprende que los campos de cultivos se encuentren fuera de la visibilidad del asentamiento romanizado, por detrás del Tossal de la Collada. La excavación y datación precisa de ambos y la confirmación del proceso de desplazamiento podrían aportar importantes elementos de datación al proceso de romanización del campo de Isona y, por ende, a la datación de ambos parcelarios.

Los asentamientos dels Horts, Serreta o casa de la Borda también coinciden con algu- 
nos límites parcelarios actuales que guardan la orientación de los antiguos y con encrucijadas de la retícula teórica, si bien generan muy poca superficie de parcelario isoclino a $28^{\circ} 30^{\prime} \mathrm{W}$. Preferimos, por tanto, limitar la relación espacial entre asentamientos y parcelario -como con el sistema coherente- a aquellos yacimientos que se encuentran en parcelarios isoclinos y no a la simple ubicación en una encrucijada o elemento lineal hipotético. Así, de los citados sólo Serreta se encuentra en una zona inmediata a dos superficies parcelaria de este sistema, lo que puede interpretarse como que el espacio de este asentamiento hubiera sido exceptuado del programa de parcelario.

Un sector donde existe una especial coincidencia de limites parcelarios activos orientados según la hipótesis propuesta es en torno al asentamiento periurbano de la Granja del Portal, aunque depende del documento utilizado. Si consideramos el plano parcelario a escala 1:5.000 existen algunos límites menores activos que presentan una orientación perpendicular al kardo que pasa por la misma granja moderna, sin embargo en la fotografía aérea no resulta tan evidente. Quizá pueda deberse a la humildad de los signos que aparecen en el parcelario, insignificantes a la escala del documento fotográico, o a una remodelación posterior a 1956 y coincidente con la construcción de la granja, que hubiera producido una coincidencia de orientaciones. No obstante, el yacimiento se encuentra inmerso en un espacio organizado por el sistema coherente pero limítrofe con un sector del parcelario centuriado.

La ermita de $N^{a} S^{a}$ de la Posa se encuentra en un cruce teórico de la retícula centuriada y en un cruce real de caminos que se adaptan muy someramente. Aunque la orientación en esta zona de relieve puede ser poco significativa, el emplazamiento de un camino empedrado que podría ser antiguo (PARCERISAS, PARPAL, REYES y SÁNCHEZ 1994), podría añadirse al corpus de datos arqueológicos que se relacionan con la propuesta de parcelario. De todas formas, sería importante definir la antigüedad del mismo y cartografiarlo en un plano a una escala grande para determinar con exactitud su coincidencia con la retícula. Lamentablemente, la inscripción dedicada a Mercurio compitali viali -protector de las encrucijadas y de los caminos- que hoy se encuentra en esta ermita, fue trasladada desde Isona en 1970 y no puede ponerse en relación con la retícula.

Para finalizar, el camino de acceso por el sur a Conques, o esta misma población, se encuentran aproximadamente en el centro de una centuria. Mientras que en Figuerola d'Orcau se encuentra un buen número de limites coincidentes con la retícula y un cruce en el emplazamiento de la iglesia y centro poblacional. La fotointerpretación en detalle del sector, permitirá discernir si se trata de la orientación natural del terreno, marcada por el río de Abella a su paso por esta población, la que ha originado una coincidencia.

\section{Interrelación de las estructuras agrarias}

Todo el espacio de la Conca se encuentra organizado por los dos sistemas quedando al margen las zonas de acusado relieve, donde la morfología agraria se ve condicionada por el compartimentado espacio que condiciona la orografía.

El sistema coherente, e hipotéticamente prerromano, presenta una mayor presencia, en parte porque ha conservado parcialmente su función: ejes de comunicación, que hoy unen las poblaciones de la Conca. El hábitat de origen medieval o post-medieval se formó fundamentalmente a lo largo de este sistema. La pendiente del terreno, por otra parte, originó y contribuyó a su perennización.

La estructura ortogonal de posible origen romano, cuya dispersión parece periférica a la estructura del sistema coherente descrito, se ubica donde no domina el sistema coherente, haciéndolo de forma discontinua. Esta impronta diferencial de ambas estructuras indica que la limitación pudo gestionar espacios no organizados por la estructura indígena o que fueron explotados de manera que sus estructuras, más difusas - pensamos, por ejemplo, en su uso como pastos-, no dejaron su impronta tras su reestructuración, "a la romana". 
Otro aspecto que llama poderosamente la atención es relación angular que mantienen ambas estructuras agrarias, de forma similar a como lo hemos documentado en Languedoc entre dos centuriaciones (FICHES, GONZÁLEZ VILLAESCUSA 1997); o entre el sistema coherente y la limitación centuriada de la ciudad iberoromana de Edeta. En este último caso las estructuras mantienen una relación angular similar aunque invertida, el sistema coherente se orienta a NG-26 $26^{\circ}$ y el parcelario centuriado a NG-35 $15^{\prime}$ E, resultando $28^{\circ} 42^{\prime}$ su diferencia (GONZÁLEZ VILLAESCUSA 2000). Aunque un sistema coherente no tiene una orientación constante, en Isona la única intersección entre dos ejes se produce entre el eje Conques St. Romà y el hipotético kardo máximo, provocando una

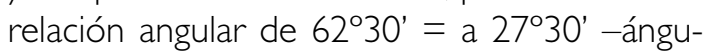
los iguales-, muy próxima a la ideal $-27^{\circ} 33^{\prime}-$, para formar un ángulo varado (ROTH CONGES 1996, 341 y fig. 38). Creando, así, una relación I, 2 de los cuadrados teóricos de las dos retículas que se superponen.

Aunque no creemos que pueda tratarse de un hecho fortuito, tampoco creemos posible una construcción del sistema centuriado a partir del sistema coherente, pues la variación constante de este último impediría obtener un parcelario de orientación constante como es la centuriación. En este caso, la estructura romana se habría construído teniendo en cuenta esta relación angular, simplemente para garantizar la clara diferenciación de las tierras mensuradas y gestionadas por ambos sistemas a partir de la diagonal de un eje anterior identificable en el suelo (ROTH CONGES 1996, 392, 40I). ¿Significaría, pues, que la construcción del parcelario centuriado se habría realizado colocando el gromae locus donde hoy se cruzan estos ejes?

En cualquier caso, la construcción de centuriaciones con una relación angular de esta naturaleza podría aplicarse también a la construcción de centuriaciones sobre diagonales de estructuras agrarias indígenas. Lo que tendría como objetivo la escasa transformación de las estructuras agrarias precedentes como ocurre en los casos de Isona y Llíria.

\section{IV.3. Funciones parcelarias}

Las prospecciones "paisajísticas", destinadas a la identificación sobre el terreno de la función agraria de las principales líneas apreciadas por carto y fotointerpretación han permitido considerar numerosos aspectos sobre la función agraria y su integración en el medio.

El sistema coherente está principalmente constituido por grandes viales que estructuran el espacio con la misma orientación que el terreno -noreste-suroeste- y un gradiente promedio del $4 \%$ que inclina hacia el suroeste. Estos viales son caminos encajados, es decir, discurren a una cota inferior que la de los campos adyacentes. En ocasiones estos caminos iban bordeados de dos muretes que los delimitaban, formando una especie de cunetas laterales entre el camino y el talud. La necesidad actual de transitar con la maquinaria agrícola por estos caminos ha acabado con la mayoría, aunque aun se conservan algunos ejemplos.

En el camí de St. Salvador de Toló pudimos observar cómo el tramo final de un camino, antes de alcanzar el barranco de la Colomera, se encajaba aún más, excavándose en un substrato de gravas, hasta superar los dos metros de desnivel respecto de los campos colaterales, en lo que creemos un intento por conservar la cota de contacto con el barranco (Fig. 14). De igual modo, uno de estos caminos al entrar en contacto con el río de Conques, tiene el significativo topónimo de Canal dels Prats. Todo lo cual permite interpretar el sistema coherente como una estructura de colectores creados para desaguar las aguas de escorrentía y conducirlas a los ríos y torrentes.

Sólo entraremos en la descripción de dos de estos caminos: la carretera de St. Romà a Conques, el más transformado por haber sido asfaltado, se sitúa a 670 m s.n.m. y desciende hasta los 580 m s.n.m., coincidiendo con el barranco de la Boïga, donde finaliza su trayecto, recorriendo $2.375 \mathrm{~m}$ y un desnivel del 3,8 \%.

El eje principal que articula todo el espacio que lleva de Isona a Abella no es completamente rectilíneo ya que atraviesa en su cami- 
no otro barranco y la propia ciudad descomponiéndose, por tanto, en tres subtrayectos que se adaptan a los distintos subsistemas hidrológicos que atraviesan. El primero empieza en la terraza izquierda del río de Abella a una altura de 800 m s.n.m. y desciende hasta el barranco de Solans, que se encuentra a $720 \mathrm{~m}$, recorriendo $1.575 \mathrm{~m}$, con un desnivel del $5 \%$. Del otro lado del barranco empieza el segundo trayecto de $2.000 \mathrm{~m}$, a una altura de $725 \mathrm{~m}$, finalizando a la entrada de la población a $670 \mathrm{~m}$ s.n.m., salvando un gradiente del 2,7 \%. Quizá, la función de colector en el emplazamiento de la antigua Isona $-662 \mathrm{~m}$ s.n.m. en el centro de la ciudad romana- fuera cumplida por el eje mayor de la ciudad o por el propio intervallum de la muralla que comparten la misma orientación. En cualquier caso, volvemos a encontrar el trazado general del itinerario bordeando el Serrat dels Espinyers -646 m s.n.m.-. El tercer subtrayecto se inicia en el camí del Solà y el camí dels Carros -bordeando un pequeño cerro- que, en un recorrido de $1.650 \mathrm{~m}$ descienden desde $620 \mathrm{~m}$ a $530 \mathrm{~m}$ s.n.m., cota a la que se encuentra el río de Conques; lo que significa una pendiente total del 5,4\%.

Las orientaciones de caminos perpendiculares nunca son ni tan largas ni demasiado frecuentes porque la Conca no ofrece una pendiente constante con esta orientación. Los diferentes arroyos que la han surcado, excavando y encajándose en el glacis plio-cuaternario han compartimentado el espacio y hacen innecesarios o menos importantes los ejes noroestesureste.

Lo que presupone una concepción del sistema tras una perfecta comprensión del medio y del paisaje $y$, en consecuencia, una planificación, no exenta de intervenciones, como la excavación en el substrato de algunos tramos para acondicionar las cotas y facilitar la evacuación de la escorrentía hacia los cursos naturales de agua, tal y como hemos podido identificar en otros medios geográficos y momentos históricos bien distintos (GONZÁLEZ VILLAESCUSA 1997, 68-69).

A diferencia del caso citado-drenaje de un marjal litoral- en Isona las líneas del sistema coherente no drenan un antiguo espacio húme- do sino que se trata de un útil de gestion de los suelos, es decir el objetivo final no es otro que el de evitar la erosión por fuertes lluvias, allí donde más pendiente hay. Lo que que podría explicar su ausencia de los terrenos llanos o con escasa pendiente propios de los espacios gestionados por el parcelario centuriado. Este tipo de construcción agraria es, en medios mediterráneos, unos de los más antiguos (POUPET 1993, 42-49) y conlleva la construcción de un sistema de terrazas coetáneo a los colectores, lo que hoy por hoy es indemostrable en la Conca Dellà.

El parcelario centuriado también dispone de caminos encajados pero son minoritarios. Al predominar en suelos llanos o con pendiente muy débil, muchos de los caminos que lo organizan no son encajados. En este caso, la perennización de la organización de un parcelario con trazados rectilíneos y ortogonales que, además, no constituyen la red viaria principal, se añade al cúmulo de indicios de su antigüedad. Un ejemplo de esta conservación de caminos cuya única función es la de jerarquizar y servir de acceso a las propiedades rurales, cuyos trazados se cortan en ángulo recto, es el sector comprendido entre les Bulles, Camp d'Abella y lo Planell. No obstante los ejes del parcelario centuriado también podrían garantizar la escorrentía de estos sectores hacia los ejes principales del sistema coherente. Circunstancia que puede ejemplificarse con el decumano del cementerio de St. Romà -que sí es encajado-, cuya prolongación conecta indirectamente con la carretera de St. Romà a Conques.

Como conclusión a la luz de todos estos datos, estamos en condiciones de afirmar que el paisaje agrario actual de la Conca tiene un aspecto antiguo, fosilizado; y no resulta vano afirmar que cualquier intervención tendente a modificarlo -una concentración parcelaria, por ejemplo-, comportaría graves consecuencias, en el supuesto de que no se considerara la lógica subyacente al diseño parcelario actual.

\section{IV.4.Propuestas de cronología}

La datación de un parcelario no puede hacerse exclusivamente por criterios morfológicos. Pese a que la interrelación real de los asenta- 
mientos rurales es un indicio de primer orden, el principal discriminador cronológico es la aportación de la excavación de estructuras agrarias. No obstante, ésta tiene sus limitaciones debido a que un fragmento cerámico en un camino o en una cuneta no aportan demasiado sobre su fecha de creación sino sobre la fecha de su utilización. Incluso la cronología de uso sólo concierne a la estructura excavada en el lugar que ha sido excavada, no pudiéndose extrapolar los datos a todo el sistema obtenido por foto y cartointerpretación (FAVORY 1996).

La labor de interpretación histórica de las estructuras agrarias de Isona empieza ahora. Se impone una tarea paciente de recolección de datos de todo tipo: excavación de hábitats específicos, excavación de estructuras agrarias, obtención de datos medioambientales, multiplicación de las prospecciones de campo...

La organización de los campos de la Antigüedad no es ajena a las formas agrarias que hemos identificado en Isona. En Languedoc, en el territorio de Nîmes, contamos con numerosos ejemplos excavados y datados fehacientemente en la protohistoria -desde el siglo $\mathrm{V}$ a. C.- hasta época romana. La estructura de estos caminos también es encajada y en ocasiones cuentan con muretes que sirven de contención de las tierras laterales, formando cunetas que también pueden servir de evacuación de las aguas en momentos de inundaciones, aún en nuestros días -información personal de C. Raynaud, CNRS-; algunos de estos caminos han sido excavados y datados en época antigua, determinando su función drenante (FAVORY et alii 1994, 177- 180 y 199-200). Otro ejemplo excavado es el camino del último cuarto del siglo I a.C., excavado en la Z.A.C. des Halles de Nímes, que disponía de muretes laterales para contener las tierras de las parcelas lindantes (MONTEIL 1993, 4I). Finalmente, uno de estos caminos que había sido identificado por fotointerpretación e integrado en una hipótesis de un sistema coherente -sistema del Vistrenque- (CHOUQUER, GONZÁLEZ VILLAESCUSA 1996, 85-88, 121 - 122; GONZÁLEZ VILLAESCUSA 1997, 12-15, 19-20, figs. 13, 14, 15, 1), fue excavado en Garons, al sur de Nîmes (SAUVAGE 1996-1997). Documentando la existencia de carriladas y materiales antiguos -ánfora itálica- en la superfice de circulación, lo que permitió verificar, al menos en este sector, la validez de la hipótesis previa.

La semejanza metrológica, formal y funcional del sistema coherente de Isona con el de Llíria-Edeta o con los citados del midi francés pone de manifiesto que la creación de los primeros paisajes agrarios pudo ser algo generalizado al mundo indígena mediterráneo de la protohistoria reciente; tal y como también se está poniendo de relieve en el mundo galo y galorromano, donde los sistemas parcelarios coherentes fechables entre los siglos III y I a.C. estructuran hasta hoy buena parte de los paisajes franceses (BUCHSENSCHUTZ 1997; CHOUQUER 1996,).

En Isona, el sistema coherente supone la estructura más integrada con el medio físico. Además, la relación que mantienen los asentamientos tardorrepublicanos y la Eso de la ceca ibérica que se encuentra en el trazado del eje principal, es indicativa de la antigüedad de la estructura (cf. II.I).

Ante el intento de datación del sistema centuriado no faltarían a la cita numerosas fechas emblemáticas. La "refundación" de Aeso (I 0080 a.C.) sobre el solar de la Eso ibérica, a raíz de las guerras sertorianas, dotada de un recinto amurallado (PRAMA 1994), con el objetivo de controlar las vías de comunicación, la población autóctona y, sobre todo, la de "servir de centro de la colonización agrícola de una comarca" (PONS 1994, 61, 81, 260), podrían ser razones para ubicar en ese momento el parcelario de tipo centuriado. En favor de estas fechas antiguas podríamos aportar algunos datos del dossier epigráfico de la ciudad como es la aparición del cognomen Numantina o Celtiber. En efecto, si la presencia de elementos vettones, arévacos o celtiberos en Lugdunum Convenarum remonta a la fundación de Pompeyo, probablemente en el contexto de asentamientos en el llano de los partidarios de Sertorio que habían huido a los Pirineos; estos cognomina de Aeso y la cronología de dicha "refundación" pueden ponerse en relación (PONS 1994, 8I), y, a su vez, podría explicarse la necesidad de una centuriación como marco territorial de las asignaciones. 
Por otra parte, el módulo utilizado de $|5 \times| 5$ actus podría apoyar un momento augusteo para el inicio de la construcción de la estructura agraria. Es un módulo poco usual pero identificado en las fundaciones augusteas de Barcino y Caesaraugusta (ARIÑO et al 1996) y en los catastros de comprensión, también augusteos, de las limitaciones de reducidos espacios físicos italianos (CHOUQUER et alii, 1987, 243 y ss.). Estas fechas también podrían apoyarse en la suposición (PONS 1994, 165) de que la municipalización de Aeso se produjese en un momento anterior a época flavia.

Cualquiera de los hechos citados son buenos candidatos a enmarcar históricamente la construcción del sistema centuriado pero insuficientes pues carecemos de elementos de datación fiables o imbricaciones fehacientes de los datos históricos y la construcción de las estructuras agrarias. En consecuencia, a la espera de esos datos, y en el contexto en que nos movemos de una pequeña ciudad de interior, es menos arriesgado proponer una estructuración del territorio, no necesariamente relacionada con los hechos mayores de la historia política citados, ni con el objetivo de instalar veteranos o de asignar tierras, sino con la intención de crear una racionalización del espacio como "instrumento de integración legible en el paisaje de las comunidades en vías de integración a la romanidad" (FAVORY 1997, I 16).

Ciertamente, cualquiera que sea la cronología del acto fundador del parcelario, sus efectos sobre el poblamiento rural no se hacen patentes hasta mediados del siglo I d.C. - entre I 50 y 50 años después de los momentos citados-, a juzgar por los materiales -sigillatas sudgálicas- recogidos en los yacimientos altoimperiales, pero sobre todo en el que genera parcelario isoclino: la villa del Cementiri de St. Romà. Aunque se trate de dataciones con materiales de prospección, por lo que pueden estar subrepresentados los momentos más antiguos, las fechas del inicio de estos asentamientos, sí que serían consecuentes con la consolidación en época de Augusto, 50 años atrás, de la red de pequeñas ciudades de la Cataluña interior (PONS 1994, 143), lo que conduciría al auge de la élite municipal aesonense a finales de ese mismo siglo y a principios del II d.C. En Aeso, por ejemplo, conocemos al benefactor $L$. Valerius Faventinus, el centurión L. Aemilius Paternus, el poeta Sextus o M. Terentius Paternus (PONS 1994, 143, 153, 174-175) entre otros documentados por la epigrafía. Élite que pudo basar sus riquezas en las remodelaciones del ager aesonensis documentadas por la eclosión de asentamientos rurales y por la organización de las estructuras agrarias.

$Y$ esto es un hecho mayor del estado actual de nuestros conocimientos. Sólo la continuidad de las investigaciones podrá aportar elementos de datación y de contexto histórico más precisos.

\section{IV.5.Consideraciones finales}

Las estructuras agrarias plantean problemas de fondo sobre la autoría de su construccción, su datación y su significado histórico. A algunas de estas cuestiones ya hemos intentado aportar soluciones; sólo queremos insistir en la primera, íntimamente ligada a la autoridad y extensión espacial de los sistemas.

La investigación actual tiende a ver en las centuriaciones una construcción menos global de lo que se ha sostenido frecuentemente $y$ el ejemplo de Aeso es una buena muestra de ausencia de encanto por el "gigantismo" de la pertica (FAVORY 1997, 99-100). Las distancias entre los sectores con más densidad de vestigios del parcelario impiden plantear una pertica global a todo el territorio, donde los sectores "vacíos" serían una pérdida de la retícula original construída.

Siguiendo la propuesta de M. Guy (1993) es posible la construcción de sectores centuriados de idéntica orientación a largas distancias; $y$, más recientemente, se ha demostrado que el recurso a la groma pudo ser menos frecuente, siendo posible la construcción geométrica de parcelarios (ROTH CONGES 1996).

La falta de atención que la investigación de las centuriaciones ha dedicado a las estructuras parcelarias indígenas, puede convertir la 
percepción de pequeñas intervenciones como la de Isona, tendentes a gestionar fundos, en gigantescas operaciones de gestión de la totalidad del territorio. En consecuencia, la retícula teórica que el investigador debe utilizar como método de búsqueda de los límites de una centuriación, acaba convirtiéndose en una retícula "retórica", -entendiendo este término como el arte de persuadir mediante el uso de instrumentos lingüísticos sin verdadero contenido. En nuestro caso si no existe más parcelario centuriado es porque probablemente nunca hizo falta construirlo, porque ya existían campos indígenas. Explicar las razones de su conservación y de la complementación de ambas estructuras no es un problema histórico menor.

En consecuencia, en muchos casos, las centuriaciones pueden nos ser más que "parcelarios a la romana", donde no es imprescindible ver el desembarco de un cuerpo técnico de agrimensores, acompañando a las legiones que dividían los campos a escuadra. Si la romanización significó la adopción de objetos de la vida cotidiana, instituciones, ideologías..., de origen itálico, por qué no también la manera de dividir los campos. Al igual que Max Guy asociaba la compra de cerámicas corintias con la construcción de parcelarios, - -difusión de técnicos o módulos métricos- $(1995,443)$, podemos preguntarnos sobre si la romanización, además de las cerámicas campanienses, las sigillatas o los cartones de mosaicos, no aportó las formas de construir los espacios agrarios. ¿Además de surgir cerámicas de imitación campaniense, pudieron surgir "centuriaciones de imitación" como consecuencia de la difusión del modelo técnico entre los técnicos -campesinos- indígenas? Desde esta perspectiva, llama la atención la semejanza métrica de los módulos -532'3 m y 525 m- de ambos sistemas, como si el módulo de 15 actus fuera el más próximo a la realidad agraria previa que encontró el agrimensor del parcelario centuriado. No se trata tampoco de un problema menor ni fácil de dilucidar.

La misma argumentación puede aplicarse al sistema coherente y la frecuencia del módulo de $525 \mathrm{~m}$. Dos casos de parcelarios de posible origen protohistórico, parecen confirmar las tesis de M. Guy, por las que el codo de 0,525 m y el pie asociado de 0,35 m se encontrarían en la base de un sistema metrológico común a todo el Mediterráneo desde los tiempos arcaicos hasta la adopción sistemática del pie romano $(1996,188)$.

El proceso de iberización de la zona es bien poco conocido y los vestigios prerromanos encontrados por el momento apuntan a momentos relativamente recientes. $\mathrm{Ni}$ de estos datos, ni de los derivados de la observación del sistema coherente puede inferirse la existencia de un poder central que lo construya; la misma observación realizada en Llíria deriva más de los numerosos datos del registro arqueológico o documental que del diseño de la estructura agraria. La adaptabilidad al medio físico de estos sistemas no permiten establecer con certeza si la regularidad observada es construída o inducida por el mismo medio. De hecho no nos cabe la más mínima duda de que, independientemente del origen antiguo del sistema, el propio medio ha impuesto sus criterios, insalvables para los agricultores medievales, modernos o contemporáneos, provocando la progresiva construcción del mismo hasta nuestros días.

\section{YACIMIENTOS Y TIPOS DE PARCELARIO. APROXIMACIÓN A UN ANÁLISIS MEDIANTE UN SISTEMA DE INFORMACIÓN GEOGRÁFICA (SIG)}

El cruce de los datos obtenidos en las campañas de prospección con la caracterización de las estructuras parcelarias nos lleva a plantear una serie de interrogantes, para cuya resolución resulta interesantes las potencialidades de los SIG.

En este caso concreto hemos utilizado el SIG denominado GRASS, acrónimo correspondiente a Geographical Resource Analysis Support System. Este producto, uno de los más veteranos entre los que estructuran la información en capas de mapas de bits o rasters, fue creado el año 1982 por el CERL (Construction Engineering Research Laboratory, http:// www.cecer.army.mil/grass/) del ejército de los 
Estados Unidos, con la finalidad de mejorar múltiples aspectos de la gestión de las importantes reservas de suelo federal que se encontraban bajo su jurisdicción.

Este programa gozó durante la década de los 80 y primera mitad de los 90 , de gran popularidad entre los arqueólogos americanos, muchos de ellos implicados en los proyectos de gestión cultural de las reservas federales citadas. Un buen testimonio de su aceptación y posibilidades nos la ofrece el volumen titulado Interpreting Space: Gis and archaeology (ALLEN et alii, 1990), verdadera obra de referencia y uno de las primeras compilaciones de monografías relacionadas con el uso de SIG en este campo.

Su difusión en Europa vino de la mano de una de las obras más influyentes en relación con la implantación de esta tecnología entre los arqueólogos de este continente. Nos referimos al estudio de Gaffney i Stancic (1991) sobre la evolución del poblamiento histórico y clásico en la isla croata de Hvar, título que, en estos momentos se puede consultar en versión HTML en la dirección http://www.zrc-sazu.si/www /pic/pub/gisbook/gisbook.htm). Numerosos proyectos de investigación y difusión han usado este programa como base, como es el Proyecto Perseus, centrado en el estudio de los paisajes de la Grecia clásica (SMITH 1995; http://www. perseus.tufts.edu/cgi-bin/atlas), el sistema estatal de gestión de datos arqueológicos de Holanda (ROORDA \& WIEMER 1992) O el estudio llevado a término en la Universidad de Carolina del Norte sobre el poblamiento antiguo del área de Bibracte (Borgoña, Francia), en el que se integraban los datos obtenidos por teledetección con los obtenidos sobre el terreno (MADRY, CRUMLEY 1991, http://deathstar.rutgers.edu /projects/france/france.html). En España, este programa ha sido utilizado por los miembros del proyecto de investigación relativo al poblamiento de la Edad del Bronce en el río Vera, Almeria (VERHAGEN et alii 1995).

A mediados de los 90 el desarrollo de GRASS parecía haberse detenido a causa de la progresiva desvinculación del CERL respecto del producto que había creado, llegando a temerse por la desaparición del mismo. La reso- lución de esta coyuntura desfavorable se produjo el mes de noviembre de 1997, cuando el CERL otorgaba el copyright de GRASS a la Universidad de Baylor (Texas) (página oficial y de la versión 5.0 - en fase beta-, http://muw.baylor.edu/ grass/), donde se crearía el Grass Ressearch Group. Desde entonces, otros profesionales investigadores en el campo del SIG han ido implicándose en el proyecto, con especial protagonismo de Markus Neteler, de la Universidad de Hannover (página oficial de la versión 4.2.l, http://www.geog.unihannover.de/grass/).

En estos momentos la continuidad del programa parece asegurada, pudiéndose afirmar que asistimos a un momento de fuerte desarrollo del producto. Diversos factores colaboran en la progresiva aceptación. En primer lugar, la alta calidad demostrado por el que probablemente sea el decano de SIG en capas raster, con más de 350 subprogramas estables que cubren funciones tan diversas como la generación de modelos digitales del terreno (MDT), operaciones algebráicas y de estadística espacial, tratamiento y rectificación de imágenes aéreas, tratamiento y análisis de datos obtenidos por sensores remotos de teledetección...

En segunda instancia, pero no menos importante, está la gratuidad y facilidad de acceso al programa. Ya desde sus inicios y dado que se desarrollaba mediante fondos federales del gobierno USA, los códigos binarios de GRASS, en sus versiones UNIX y Linux (también existe una versión gratuita para MkLinux, que funciona en ordenadores Mac, así como algunas versiones comerciales para Windows) se distribuyen sin ningún coste a los que puede accederse libremente a través de Internet.

En último lugar, sus usuarios valoran especialmente el volumen y cantidad de información disponible relativa al programa, tanto a traves de la red (en las webs del programa y, especialmente, en los foros de discusión info.grass.user, info.grass.programer y en http://grassnet.baylor.edu), como del CDrom con binarios y documentación que ofrece a muy bajo coste el grupo que trabaja en la Universidad de Hannover. 
En esta primera aproximación a las estructuras agrarias del ager aesonensis concentraremos los esfuerzos en intentar profundizar en dos interrogantes que nos parecen fundamentales. De un lado, nos ocuparemos de la relación cronológica existente entre los asentamientos y localizaciones de época romana y los diferentes tipos de parcelario identificados mediante fotointerpretación.

De otro, intentaremos establecer si, al relacionar las diferentes áreas ocupadas por un determinado tipo de parcelario com mapas temáticos, se recoge información relativa a variables ambientales como la pendiente, la orientación del terreno, la acumulación superficial del agua, la geomorfología, si se aprecia una preferencia clara hacia unos rasgos determinados a partir de los cuales se pueda inferir la orientación económica que animaba las diferentes operaciones de gestión de los espacios agrarios que se han documentado a través de la fotointerpretación.

\section{V.I. El yacimiento como punto de referencia}

Ciñéndonos, en primera instancia, al lugar concreto donde se localizan materiales arqueológicos, o dónde están las estructuras que conforman los yacimientos, se puede decir que de los trece puntos identificados en el área de estudio, cuatro se sitúan en terrenos con morfologías parcelarias indiferenciadas, normalmente, en puntos dominantes $\mathrm{o}$ áreas con fuerte pendiente. De estos cuatro dos tienen su origen en el período tardoibérico/republicano (Aeso y les Aunoves), mientras que los restantes aparecen durante la etapa altoimperial (La Bastida i Llorís). Por otra parte, sólo una de las localizaciones, la Tosca del Pauet, se encuentra en un fondo de valle parcelado, morfología que creemos que se configura en el periodo medieval y/o moderno, y que, en este último caso, habría sustituido formas parcelarias preexistentes o espacios no parcelados.

Respecto a los dos tipos más representados, el sistema coherente y el parcelario centuriado, es especialmente ilustrativo que de los ocho asentamientos o localizaciones identificadas en estas categorías, siete se producen en el interior de la primera y sólo uno en la segunda.

Incidiendo en esta misma dirección, resulta revelador que de los citados ocho puntos, los tres que corresponden al periodo tardoibérico/republicano (Tossal de la Collada, La Serreta y Els Horts) se localicen en el sistema coherente, tal y como sucede con cuatro de los originados en época altoimperial (El Serrat, la Granja del Portal, Els Prats y la Casa de la Borda). Sólo uno de los asentamientos altoimperiales, concretamente y de forma siginificativa el del Cementiri de Sant Romà, único que podemos asignar sin dudas a la categoría de villa, se localiza en el interior del parcelario centuriado.

Tabla I. Distribución de los yacimientos en función del parcelario

$\begin{array}{lccc} & \begin{array}{c}\text { Tardo-ibéricos } \\ \text { y republ. }\end{array} & \begin{array}{c}\text { Alto- } \\ \text { imperiales }\end{array} & \text { Total } \\ \text { Indiferenciado } & 2 & 2 & 4 \\ \text { Sist. Coherente } & 3 & 4 & 7 \\ \text { Parc. Centur. } & 0 & 1 & 1 \\ \text { Fondo de valle } & 0 & 1 & 1 \\ \text { Huertas } & 0 & 0 & 0\end{array}$

Llegados a este punto, merece preguntarse si la inexistencia de localizaciones o de asentamientos tardoibéricos o republicanos de los bloques parcelarios donde predominan los límites de tipo centuriado, constituye una prueba más de la ya propuesta posterioridad de esta forma de organización del espacio agrario respecto al sistema coherente. Aún más, hasta qué punto no es una prueba de la constante preferencia manifestada respecto a estas últimas áreas, no sólo para residir en ellas, sino también, sobre todo, como espacios para desarrollar los trabajos agropecuarios mejor conceptuados.

Con la consolidación de la pax augustea, se producirá el abandono de algunos de los asen- 
tamientos de altura, como Les Aunoves o el Tossal de la Collada, que se desplaza hacia el llano situado al pie de esta elevación, dando lugar a la aparición de la localización denomianda Tosca del Pauet. Este abandono de posiciones con un marcado componente defensivo viene acompañada por la densificación de la red de ocupación del territorio y la aparición de nuevos asentamientos campesinos. Sus habitantes, cuando escogieron los nuevos emplazamientos, parecen haber optado mayoritariamente por las áreas ordenadas por el sistema coherente en detrimento de las zonas con parcelario de tipo centuriado que, en aquel momento, debía encontrarse en proceso de configuración. Al tomar esta decisión, ¿cuáles son los motivos que les guiaron? Tradicionalismo, desconfianza hacia una operación de parcelario concebida desde fuera del grupo campesino o, simplemente, ¿opción por profundizar en la explotación de los terrenos percibidos como más rentables? O quizá una forma de explotación de algunas tierras gestionadas por el parcelario centuriado que no deja restos perceptibles en el registro arqueológico o, incluso, un fallo de éste.

\section{V.2. Ampliando la perspectiva: las áreas de parcelario como foco de atención}

Estas impresiones, formadas a partir de la observación del lugar exacto donde se encuentran los asentamientos, se ven confirmadas si ampliamos el campo de análisis a un radio de quinientos metros alrededor de estos puntos. La opción por esta distancia y no otra tiene su razón de ser en la densidad de ocupación que, a partir de los datos obtenidos en prospección, puede establecerse para esta zona y el total del periodo romano. En las once cuadrículas de un kilómetro cuadrado que fueron prospectadas de forma sistemática se encontraron un total de otros tantos yacimientos (conocemos otros dos dentro de la zona por medio de otras prospecciones no sistemáticas). Por esta razón les asignamos un área teórica de un kilómetro, aunque somos conscientes que el espacio sobre el cual desplegaban sus actividades estos asentamientos posiblemente fuera más reducido, dado que no en todas las cuadrícu- las se localizaron asentamientos (en tres de once no se recogieron materiales de época romana).

Así, se procedió a sumar el número de hectáreas de cada uno de los tipos de parcelario presentes en el interior de dichos cículos o buffers de $500 \mathrm{~m}$ de radio, así como a calcular su porcentaje. Estas cifras fueron comparadas con las del conjunto del área de estudio con tal de verificar o falsear una hipótesis nula del siguiente tipo: los asentamientos se distribuyen aleatoriamente por el espacio tomado en consideración (un área de $5 \times 6 \mathrm{~km}$ ), sin que en la opción por un emplazamiento $u$ otro haya influenciado el tipo de parcelario sobre el que se instalan y/o que se encuentra a su alrededor.

Para hacer esta comprobación comparamos los patrones de preferencia observados en el interior del buffer con el teórico o previsto. Este último se obtiene al distribuir el número total de hectáreas que corresponden a los buffers de los yacimientos tardoibéricos/republicanos o altoimperiales, en función del porcentaje de cada una de las morfologías parcelarias en el conjunto del área de estudio (SHENNAN I988, pp. 66-67). En el caso que el valor observado y el previsto sean similares podremos hablar de aleatoriedad en el proceso de selección del lugar de residencia, al menos en función de la variable "tipo de parcelario". Por el contrario, si ambos valores se alejan por exceso o defecto podremos inferir la existencia de predilección o rechazo hacia un tipo determinado de organización del terrazgo y posiblemente, respecto de las prácticas agropecuarias a las cuales sirven como soporte.

Tanto en el caso de yacimientos de época tardoibérica y republicana como de los correspondientes al momento altoimperial, la aplicación del test de X2 (con cuatro grados de libertad y un nivel significación del 0,05) permite rechazar la hipótesis nula y establecer que en los respectivos procesos de elección del lugar de asentamiento se tuvo en cuenta el tipo de parcelario (y las actividades económicas) que había alrededor, o que iba a haberlo en un futuro. 
Tabla 2. Yacimientos tardoibéricos y republicanos (radio de $500 \mathrm{~m}$ )

$\begin{array}{lcc}\text { Tipo parcelario } & \text { Ha. conservadas } & \text { Ha. previstas } \\ \text { Indiferenciado } & 187,72 & 171,73 \\ \text { Sist. Coherente } & \mathbf{1 0 7 , 2 3} & 98,17 \\ \text { Parcelario Centur. } & \mathbf{3 5 , 3 6} & 58,17 \\ \text { F. de valle parc. } & 17,86 & 16,40 \\ \text { Huertas } & 0,97 & 4,67 \\ \text { Total } & 349,14 & 349,14\end{array}$

Tabla 3. Yacimientos altoimperiales (radio de $500 \mathrm{~m}$ )

$\begin{array}{lcc}\text { Tipo parcelario } & \text { Ha. conservadas } & \text { Ha. previstas } \\ \text { Indiferenciado } & 221,35 & 295,4681368 \\ \text { Sist. Coherente } & \mathbf{2 3 6 , 6 4} & 168,9024400 \\ \text { Parcelario Centur. } & 94,80 & 100,0839568 \\ \text { F. de valle parc. } & 36,75 & 28,2258304 \\ \text { Huertas } & 11,18 & 8,0396360 \\ \text { Total } & 600,72 & 600,72\end{array}$

En lo que respecta a los primeros, apreciamos un número de hectáreas observadas que ultrapasan las teóricas, tanto para las áreas con tipo de parcelario no diferenciados (colinas, yermos, bosques...) como para las correspondientes al sistema coherente, mientras que los valores previstos para el parcelario centuriado son superiores a los observados.

Estas observaciones resultan congruentes con la hipótesis avanzada sobre la existencia de una estrecha relación entre el sistema coherente y el poblamiento tardoibérico y republicano, con asentamientos que pretenden un equilibrio entre las posiciones relativamente elevadas y defendibles facilmente, de un lado, y la proximidad a los terrenos de cultivo o pastizales donde desarrollan su actividad económica. Unos terrenos, en definitiva, que no serían otros que los correspondientes al citado sistema coherente. La diferencia negativa respecto a los valores que teóricamente debería relacionarse con el parcelario de tipo centuriado en torno a estos yacimientos puede justificarse desde la perspectiva de la instalación de éste con posterioridad a la fijación del hábitat. El nuevo tipo de limitación parcelaria enmascararía parcial- mente las trazas del anterior o no ocuparía determinados espacios que había quedado al margen de la organización previa del terrazgo.

Al analizar los buffers trazados alrededor de los yacimientos altoimperiales apreciamos que estos coinciden con los precedentes en su preferencia por las áreas ordenadas por el sistema coherente, una preferencia aún más acentuada que la que se observaba durante la fase previa (30,7\% de ha observadas frente al 27,I $\%$ de las previstas en época tardoibérica y republicana, mientras que en la altoimperial los porcentajes se elevan al 39,3 contra el 28, I, respectivamente).

Respecto al parcelario centuriado, los valores observados nos sitúan casi un punto porcentual por debajo de los previstos ( $15,7 \%$ frente al 16,6\%). La impresión de que los asentamientos rurales creados a partir del principado de Augusto manifiestan una escasa predilección por aquellas áreas que se están organizando "a la romana" en ese mismo momento se acentúa aún más si prestamos atención al hecho de que de las 98,8 ha organizadas de forma isoclina presentes en los buffers trazados alrededor de los ocho yacimientos correspondientes a este periodo, casi un tercio $(30,7$ ha) se encuentran alrededor de un único asentamiento, el Cementiri de Sant Romà d'Abella, único que podemos adscribir a priori en la categoría clásica de una villa.

Parece, pues, que, al menos en lo que respecta a la variable "tipo de parcelario", nos encontramos frente a dos categorías diferenciadas de asentamientos, de un lado, núcleos de dimensión media y pequeña con estructuras constructivas ligeras (salvo el yacimiento de la Bastida, donde se localizó un contrapeso de prensa, el resto sólo proporcionaron dispersiones de material cerámico), que optan claramente por aproximarse a las áreas organizadas mediante el sistema coherente; por otro, un único yacimiento de gran tamaño, del que hemos podido documentar abundantes restos edilicios (muros, pavimentos de opus signinum, molduras de mármol, restos escultóricos, hornos...), que construye alrededor suyo un parcelario isoclino. Una auténtica villa, en definitiva. 
En última instancia, la representación que se obtiene tanto para los yacimientos tardoibéricos/republicanos como altoimperiales respecto de los parcelarios de fondo de valle y los de huerta, otras dos categorías individualizadas en el área de estudio, muestra un comportamiento muy próximo de los valores previstos. Algo, por otra parte comprensible, si como creemos, la implantación de estas últimas formas de articulación del paisaje rural se produce con bastante posterioridad respecto del periodo que nos ocupa.

\section{V.3. Los tipos de parcelario en su marco paisajístico}

Una vez que hemos intentado establecer la existencia de una relación entre los yacimientos documentados a lo largo de las campañas de prospección de las áreas articuladas por uno u otro tipo de parcelación, el siguiente paso era intentar establecer los usos agropecuarios para los que fueron concebidos los escenarios de la producción campesina y los asentamientos que se encuentran en su proximidad.

La consecución de este último objetivo se ve fuertemente obstaculizada por el hecho de no disponer, por el momento, de análisis palinológicos, paleocarpológicos..., que contribuyan a conformar una reconstrucción paleoambiental fidedigna del entorno de la ciudad de Aeso. Sin embargo de la interrelación de distintas variables se pueden obtener algunas conclusiones de utilidad a la hora de aproximarnos a la problemática relación existente entre forma y función del parcelario.

Al abordar la relación entre tipologías parcelarias y variables ambientales asumimos, con ligeras modificaciones, las dos premisas fundamentales empleadas por las técnicas de modelización predictiva aplicadas a yacimientos. En primer lugar, que las opciones por uno o otro asentamiento (en este caso, para aplicar a una o otra zona un tipo determinado de organización de suelo agrícola) están fuertemente influenciadas o condicionadas por las características del entorno natural. En segunda instancia, asumimos que los factores ambientales que influyen directamente sobre las mencionadas opciones se encuentran reflejados, al menos indirectamente, en la moderna cartografía ambiental de que disponemos para la zona de estudio (WARREN 1990, p. 202).

Las variables ambientales que tomamos en consideración son las siguientes: orientación del terreno, pendiente o inclinación y categoría geomorfológica. Al final, y para poder contrastar las hipotéticas preferencias mostradas por el sistema coherente y el parcelario centuriado por determinadas condiciones ambientales, introduciremos una variable como la de la categoría actual de uso del suelo, en que se combinan los factores ambientales con los sociales en un marco temporal diferente de aquel en el que centramos nuestra atención.

Consideramos la variable de orientación cardinal del terreno, estrechamente ligada a la capacidad de insolación, como una variable muy relevante en esta zona puesto que las heladas invernales constituyen, aún hoy en día, un factor crítico determinante de la producción agrícola. Se han obviado las zonas de umbría para cultivar determinados productos especialmente sensibles a las heladas, a la vez que para otras se buscan tierras no demasiado expuestas a la intensa insolación estival.

Para simplificar la utilización de esta variable se han reclasificado los valores calculados para cada celda a partir del modelo digital del terreno (de 0 a 360 grados), reduciéndolos a ocho rangos de 45 grados cada uno, de forma que el rango N-NE corresponde a los valores comprendidos entre 0-45 grados, el NE-E entre 46-90, y así sucesivamente hasta completar los 360 grados.

La comparación entre esta variable y las dos morfologías parcelarias antiguas que nos ocupan muestra significativas diferencias en una y otra operación de ordenación del paisaje agrario. Es cierto que tanto el sistema coherente como el parcelario centuriado manifiestan una clara preferencia hacía las tierras de orientación comprendida entre SE-SW, pero también lo es que fuera de este rango de coincidencia este comportamiento es simétricamente contrario. 
Así, el sistema coherente sigue la tónica del área en las orientaciones comprendidas entre $\mathrm{SW}-\mathrm{W}$ y NW-N, mientras que se relaciona de forma negativa con los rangos que oscilan entre N-NE y E-SE. Justo al contrario de lo que sucede con el parcelario coherente.

Tabla 4. Relación parcelario-orientación

\begin{tabular}{lcccc} 
& \multicolumn{2}{c}{ Coherente } & \multicolumn{2}{c}{ Centuriado } \\
& $\begin{array}{c}\text { Observado } \\
\text { (ha) }\end{array}$ & $\begin{array}{c}\text { Previsto } \\
\text { (ha) }\end{array}$ & $\begin{array}{c}\text { Observado } \\
\text { (ha) }\end{array}$ & $\begin{array}{c}\text { Previsto } \\
\text { (ha) }\end{array}$ \\
N-NE & 90.89 & 119.79 & 88.57 & 70.98 \\
NE-E & 21.08 & 49.36 & 17.40 & 29.25 \\
E-SE & 78.39 & 106.69 & 63.70 & 63.23 \\
SE-S & 173.42 & 135.50 & 105.25 & 80.29 \\
S-SW & 188.61 & 157.63 & 140.78 & 93.40 \\
SW-W & 127.46 & 121.19 & 45.96 & 71.80 \\
W-NW & 122.81 & 111.45 & 32.07 & 66.05 \\
NW-N & 40.84 & 41.89 & 6.09 & 24.82 \\
Total & $\mathbf{8 4 3 . 5}$ & $\mathbf{8 4 3 . 5}$ & $\mathbf{4 9 9 . 8 2}$ & $\mathbf{4 9 9 . 8 2}$
\end{tabular}

Creemos que esta simetría es posible interpretarla como resultado de la superposición al sistema coherente previo de un nuevo parcelario, el centuriado, que se desarrolla en espacios marginales o desatendidos por la morfología preexistente. Un buen ejemplo podría ser la atención relativamente mayor prestada por la posible intervención de época alto imperial hacia los suelos orientados a E-SE, esto es, la mayor insolación matutina.

A la vez, el sistema coherente muestra una relación fuertemente negativa respecto del rango de orientaciones comprendido entre $\mathrm{N}$ NE y NE-E (también con E-SE, pero puede ser causa de la mencionada superposición del parcelario centuriado), hecho que podría indicar que en estas tierras se desarrollan cultivos especialmente sensibles a las heladas. Aunque, atendido el papel estructurador que en este sistema parecen tener los caminos excavados por debajo de la cota del terreno circundante, no debe descartarse la posibilidad que, a falta de un índice adecuado de evapotranspiración de los suelos, se recurriera a la excavación de caminos que a la vez actuasen como colectores de la humedad sobrante.
En el caso de la variable pendiente se ha procedido a simplificar los valores obtenidos a partir del modelo digital del terreno, originariamente expresados en grados respecto del plano horizontal, reclasificándolos en cuatro categorías o rangos que nos han parecido significativos. Estos son: pendiente muy suave (entre 0 y 5 grados), pendiente ligera (entre 6 y 10 grados), pendiente moderada (entre 11 y 15 grados) y pendiente fuerte (> I5 grados).

A juzgar por las anteriores cifras y por el gráfico que acompaña estas líneas resulta evidente la preferencia del parcelario centuriado por los terrenos con pendiente muy suave (casi un 65 $\%)$, frente a un sistema coherente los porcentajes del cual $(48,4 \%)$ se encuentran muy cerca de los del conjunto del área (45,9\%). En cambio cuando se pasa al siguiente valor de la variable, el de terrenos con pendientes comprendidas entre 5 y 10 grados, la tendencia se invierte; el sistema coherente se situa claramente por encima de los del valor del área (37,2\% frente a $32,8 \%$ ), muy por encima del $23,9 \%$ manifestado por el parcelario centuriado.

De todo esto parece que se puede extraer la idea que el sistema coherente, si como se piensa es el más antiguo de los conservados e inicialmente cubría la práctica totalidad del área sometida a análisis, habría resultado especialmente adecuado para terrenos con alguna inclinación y solo habría sido necesario o interesante sustituirlos por la ordenación centuriada en aquellas zonas estrictamente llanas o con una pendiente mínima. La marcada relación negativa entre parcelario centuriado y rangos de pendiente superiores a los 5- 10 grados es, según parece, un indicio claro.

Tabla 5. Relación parcelario-orientación

\begin{tabular}{|c|c|c|c|c|}
\hline & \multicolumn{2}{|c|}{ Coherente } & \multicolumn{2}{|c|}{ Centuriado } \\
\hline & $\begin{array}{c}\text { Observ. } \\
\text { (ha) }\end{array}$ & $\begin{array}{l}\text { Previsto } \\
\text { (ha) }\end{array}$ & $\begin{array}{l}\text { Observ. } \\
\text { (ha) }\end{array}$ & $\begin{array}{c}\text { Previsto } \\
\text { (ha) }\end{array}$ \\
\hline Muy suave $\left(0-5^{\circ}\right)$ & 408.35 & 387.44 & 324.80 & 229.58 \\
\hline Suave $\left(5-10^{\circ}\right)$ & 314.69 & 277.08 & 119.56 & 164.18 \\
\hline Moderado $\left(11-15^{\circ}\right)$ & 94.15 & 117.03 & 35.96 & 69.36 \\
\hline Fuerte $\left(>16^{\circ}\right)$ & 26.31 & 61.95 & 19.50 & 36.70 \\
\hline
\end{tabular}

Total $843.5 \quad 843.5$ 
La variable unidades geomorfológicas se obtiene a partir de la digitalización de un mapa a escala 1:5.000 (PEÑA 1983, correspondiente a la hoja 290 del IGN) y de su superposición al modelo digital del terreno efectuado a partir de cartografía de escala 1:25000. Somos conscientes que este proceso, y teniendo en cuenta que no se ha hecho una tarea de comprobación sobre el terreno, se debe haber introducido un error no negligible. A la vez, en el documento original, buena parte de los contactos entre formaciones se producen mediante laderas que, en buena lógica (al menos desde el punto de vista de composición), se deberían adscribir a alguna de las formaciones que interrelacionan. Así, como el documento cartográfico mencionado no lo especifica, se ha optado por digitalizarlas como laderas indiferenciadas.

La razón por la que se acepta este grado de error no es otra que la necesidad de contar con alguna variable ambiental que haga referencia al soporte geológico, ya que no se cuenta con ninguna carta edafológica de la zona.

Tabla 6. Relación parcelariounidades geomorfológicas

\begin{tabular}{|c|c|c|c|c|}
\hline \multirow{2}{*}{$\begin{array}{l}\text { Unidades } \\
\text { geomor- } \\
\text { fológicas }\end{array}$} & \multicolumn{2}{|c|}{ Coherente } & \multicolumn{2}{|c|}{ Centuriado } \\
\hline & $\begin{array}{l}\text { Observado } \\
\text { (ha) }\end{array}$ & $\begin{array}{l}\text { Previsto } \\
\text { (ha) }\end{array}$ & $\begin{array}{l}\text { Observado } \\
\text { (ha) }\end{array}$ & $\begin{array}{c}\text { Previsto } \\
\text { (ha) }\end{array}$ \\
\hline Barrancos & 1.65 & 16.14 & 1.56 & 9.57 \\
\hline Vert. Soliff. & 0.00 & 33.12 & 0.00 & 19.63 \\
\hline Toscas & 2.26 & 37.64 & 5.54 & 22.31 \\
\hline Glacis bajo & 193.29 & 199.77 & 174.40 & 118.38 \\
\hline Terraza inferior & 58.54 & 62.94 & 21.22 & 37.30 \\
\hline Valle fondo plano & 49.92 & 63.98 & 16.80 & 37.90 \\
\hline Nivel PI-C & 138.06 & 73.08 & 39.39 & 43.31 \\
\hline Glac. Medio-alto & 173.53 & 129.94 & 121.64 & 76.99 \\
\hline Vertindif. & 226.25 & 226.89 & 119.27 & 134.43 \\
\hline Total & 843.5 & 843.5 & 499.82 & 499.82 \\
\hline
\end{tabular}

De la observación de las tablas y gráficos adjuntos se desprende la idea de una relación muy similar $y$, a priori, poco significativa entre los dos sistemas antiguos de organización del paisaje agrícola y la variable unidades geomorfológicas. El parecido comportamiento de los dos tipos de parcelario queda bien reflejado por valores como el del glacis medio-alto, que representa un 20,57\% de las hectáreas adscritas a los sistemas coherentes o un 24,33\% del parcelario centuriado frente al 15,40\% para el conjunto del área.

Por contra, un par de valores divergen significativamente de la pauta común al conjunto del área. Nos estamos refiriendo al glacis bajo, un caso especialmente significativo debida a su importancia cuantitativa, terrenos hacía los que parecen haber mostrado una especial predilección los creadores del parcelario centuriado $34,89 \%$ frente al $22,91 \%$ correspondiente al parcelario centuriado y del $23,68 \%$ del conjunto del área). También el valor nivel PI-C demuestra tener una cierta importancia a la hora de perfilar las áreas sobre las que se establecerá el sistema coherente (16,36\% frente I 7,88 del parcelario centuriado y $8,66 \%$ del conjunto del área).

Así pues, el sistema coherente, muestra cierta predilección por los niveles plio-cuaternarios (PI-C) y por el glacis medio-alto que se desarrolla a sus pies, mientras que el parcelario centuriado parece adaptarse mejor al glacis y a las terrazas bajas, aunque también tiene cierta presencia por encima de la mediana en el mencionado nivel PI-C.

De todo lo que precede quizás se podría inferir cierta especialización de los parcelarios centuriados hacia:

I. Terrenos llanos con ladera mínima

2. Terrenos que reciben un grado máximo o muy alto de insolación

3. Terrenos con una alta capacidad para retener el agua que circula por su superficie, como seria el caso de las terrazas y de los glacis bajos. Aunque también tiene una presencia importante en tierras bien drenadas, como las de los niveles pliocuaternarios de la Conca. 
Por el contrario, el llamado sistema coherente no presenta una definición tan perfilada, dando la impresión de haber sido una creación mucho más versátil y con voluntad de organizar la máxima cantidad de superficie dentro del área de estudio. A pesar de todo, se pueden apuntar algunos parámetros que orientan sobre los lugares donde es más probable identificar esta morfología parcelaria:

I. Terrenos con pendientes ligeras, especialmente aquellos que se sitúan entre los 5 y 10 grados.

2. No se muestra especialmente exigente por lo que respecta a la orientación y al grado de luz que puede recibir.

3. Suelos formados dentro del ámbito de los niveles pliocuaternarios y los glacis medianos-altos que bajan desde los relieves de Abella y Sant Corneli en dirección NE-SW y que presentan una capacidad muy alta de drenaje.

Para poder contrastar las tendencias apuntadas, se ha llevado a cabo una última comparación entre las dos tipologías de parcelario hipotéticamente romanas o anteriores y una cartografía de usos actuales. Esta información ha sido extraída del Mapa de Cultivos y Aprovechamientos, Isona, hoja 290/33-I2 del Ministerio de Agricultura, Pesca y Alimentación (1990). Como ya se comento en el párrafo correspondiente a las unidades geomorfológicas, también aquí se ha tenido que extrapolar los datos de una cartografía de usos a escala 1:50.000 y ajustarla (sin haber efectuado mediciones de comprobación sobre el terreno) al modelo digital del terreno a escala 1:25.000 que ha servido de base a lo largo de este artículo.

Somos conscientes que al incorporar este tipo de datos, se introduce una variable que solo es parcialmente ambiental, pero que a la vez tiene el atractivo de ser el resultado de una serie de opciones similares a aquellas con las que posiblemente se tuvieron que enfrentar los campesinos de época ibérica tardía y romana: decidir cual es la estructuración de los campos más correcta para un uso agropecuario determinado y, en caso de no encontrarse ninguna de satisfactoria, crear una nueva.

Del cruce de las dos morfologías agrarias con el mapa de usos del suelo actual se desprende una serie de preferencias en las que haría falta profundizar, para establecer hasta que punto la coincidencia entre un uso del suelo actual y la presencia en su área de determinados trazos parcelarios responden a una aleatoriedad, o bien son fruto de una larga perduración.

Tabla 7. Relación parcelario antiguo-usos actuales

\begin{tabular}{lcccc|}
\multicolumn{1}{c}{$\begin{array}{c}\text { Usos del } \\
\text { suelo }\end{array}$} & $\begin{array}{c}\text { Observado } \\
\text { (ha) }\end{array}$ & $\begin{array}{c}\text { Previsto } \\
\text { (ha) }\end{array}$ & $\begin{array}{c}\text { Observado } \\
\text { (ha) }\end{array}$ & $\begin{array}{c}\text { Previsto } \\
\text { (ha) }\end{array}$ \\
Frutales de secano & 241.51 & 186.75 & 148.54 & 109.50 \\
Labor intensiva & 290.76 & 333.74 & 218.11 & 195.68 \\
Matojos & 85.66 & 144.11 & 89.27 & 84.50 \\
Pastos & 0.00 & 1.16 & 0.00 & 0.68 \\
Cult. herb. regadío & 95.07 & 57.36 & 9.93 & 33.63 \\
Improductivo & 31.14 & 31.53 & 0.00 & 18.49 \\
Huertos & 0.27 & 1.22 & 0.00 & 0.72 \\
Bosque & 99.09 & 87.63 & 28.73 & 51.38 \\
Total & $\mathbf{8 4 3 . 5}$ & $\mathbf{8 4 3 . 5}$ & $\mathbf{4 9 4 . 5 8}$ & $\mathbf{4 9 4 . 5 8}$
\end{tabular}

Total

$\mathbf{8 4 3 . 5} \quad 843.5$

$494.58 \quad 494.58$

El sistema coherente solo muestra dos valores que se alejan, aunque de forma poco rotunda, respecto de los valores medianos del área. Estos son los frutales en secano (almendros, fundamentalmente, olivos, menos) y los cultivos herbáceos en regadío (básicamente forrajes y otras gramíneas).

Podría interpretarse esta última preferencia aparente por espacios donde hoy se practica el regadío como un indicio que apoyará la tesis ya apuntada sobre que esta forma de organización de la tierra, y en especial la red viária que se le asocia, hayan desarrollado funciones de drenaje. Esta observación añadida a las que se poseen a través de la comparación con las variables ambientales, permite albirar, detrás de la amplitud del espectro de usos agrícolas cubiertos por esta morfología, una ligera especialización 
de las zonas con más posibilidades por el regadío o mayor presencia del agua en el terreno.

El parcelario centuriado también muestra una fuerte asociación con las zonas donde se cultivan cereales con labor intensiva o barbecho sembrado, así como también con el cultivo de frutales de secano. A la vez, la presencia dentro del área donde predomina esta morfología parcelaria de cultivos herbáceos en regadío es la más baja $(1,98 \%)$ de las cinco identificadas al conjunto del área (6,8\%).

\section{V.4. Los cultivos probables}

La mayor insolación favorece a los cultivos típicamente mediterráneos (FAVORY et alii 1995). El trigo necesita que el suelo en que se encuentra seque pronto con las lluvias primaverales. La vid necesita de primaveras y otoños sin sorpresas, terrenos bien drenados y abundante insolación. El olivo, por su parte, es el indicador septentrional del clima mediterráneo y precisa de un invierno dulce y una gran luminosidad (=insolación). Dada las condiciones climáticas de Isona, podemos suponer que estas condiciones sólo se darán en las zonas con mayor insolación.

Los datos de que disponemos para los suelos de la zona (MINISTERIO DE AGRICULTURA, PESCA Y ALIMENTACION 1990, pp. II-13), aunque sin un mapa que localice las distintas taxonomías, permiten establecer que en el fondo de la Conca dominan los Inceptisoles, suborden Ochrepts y Xerochrepts. Lo que viene a querer decir que se trata de suelos pardos calizos, según se deduce por el material de origen que los genera. Aunque sin que podamos saber demasiado de las texturas parece haber un predominio de las ligeras (franco-arenosas).

En síntesis son características que F. Favory, tras un estudio detallado sobre la percepción de los suelos por parte de los antiguos, asocia con los cultivos típicamente mediterráneos (FAVORY et alii 1995).

En el mismo trabajo, F. Favory (FAVORY et alii 1995) concluye que los criterios de fertilidad y de capacidad agronómica de los suelos difieren si consideramos la Antigüedad o la actualidad como marco temporal de referencia. "En la Antigüedad se juzgan como tierras fértiles las tierras de trigo y los terrenos convenientes a las especies más emblemáticas de la arboricultura mediterránea: el olivo y la viña." Es decir, para el trigo los suelos calizos o de acumulación caliza, las tierras negras o cenicientas, arcillo-calizos o arcillo silíceos dotados de una reserva hídrica. Para el olivo y la viña serían óptimos los suelos poco profundos, ligeros, más bien secos, cálidos, generalmente calizos, arenosos e incluso pedregosos, o incluso las tierras rojas (arcillosas). A falta de mejores estudios edafológicos, podemos suponer que estos son, con un margen de error no muy grande, los suelos de la Conca.

Si añadimos los datos de la orientación/insolación estamos en condiciones de establecer una hipótesis de partida que consistiría en que los suelos preferidos por la centuriación son los más aptos para los cultivos mediterráneos $y$, por tanto, óptimos para los romanos y sus instalaciones de villae.

Faltaría poder saber si esos suelos ya habían sidos puestos en cultivo o si, por el contrario, se trataba de espacios no usados por los iberos. Nos falla, muy probablemente, un factor de estrategia de producción en relación con esta sociedad (ila ganadería?). Quizá, por razones que todavía no se pueden acabar de formalizar, preferían las tierras que aprovecharan mejor la humedad remanente del terreno, cerca de los valles y vaguadas.

\section{BIBLIOGRAFÍA}

ALLEN, K.M.S.; GREEN, S.W.; ZUBROW, E.B.W. 1990. Interpreting Space: Gis and Archaeology. Taylor \& Francis. London - New York - Philadelphia.

ARIÑO GIL, E.; GURT ESPARRAGUERA, J.M.; PALET MARTINEZ, J.M. 1996. "Réalités archéologiques et restitution théorique des parcellaires: analyse du problème sur quelques exemples hispaniques", en Chouquer (ed.), Les Formes du Paysage. Tome 2- Archéologie des parcellaires, París, pp. 142- 154. 
BESSAC, J.L.; CHRISTOL, M.; FICHES, J.L.; GASCO, Y; JANON, M.; MICHELOZZI, A.; RAYNAUD, C.; ROTHCONGES, A.; TERRER, D. 1987. Vgernvm. Beaucaire et le Beaucairois à l'époque romaine, A.R.A.L.O., Caveirac.

BRADLEY, R. RICHARDS J. 1978. "Prehistoric fields and boundaries on the Berkshire Downs", dans BOWEN, H.C., FOWLER, P.J. (éd.), Early land allotment, BAR British Series 48, Londres.

BUCHSENSCHUTZ O. 1997. "Reflexions sur les parcellaires de l'Âge du Fer en France septentrionale", en La dynamique des paysages protohistoriques, antiques, médiévaux et modernes, XVII Rencontres Internationales d'Archéologie et d'Histoire d'Antibes, Sophia Antipolis, pp. 13-20.

BUTZER, W.K. 1989. Arqueología, una ecología del hombre, Barcelona, 1989.

CHOUQUER, G. 1983. "Dégradation et fossilisation des cadastres centuriés. Étude morphologique", en M. ClavelLévêque, (dir.), Cadastres et Espace rural. Approches et réalités antiques. Table ronde de Besançon, mai 1980, París, pp. 137-I57.

CHOUQUER, G. 1996. "Parcellaires et longue durée. Points de repère historiques et problèmes d'interprétation", en Chouquer (ed.), Les Formes du Paysage. Tome 2- Archéologie des parcellaires, París, pp. 201-222.

CHOUQUER, G.; CLAVEL-LÉVEQUE, M.; FAVORY, F.; VALLAT, J.P. 1987. Structures agraires en Italie centro-méridionale. Cadastres et paysages ruraux, Collection de l'École Française de Rome, Roma.

CHOUQUER, G.; GONZÁLEZ VILLAESCUSA, R. 1996. "Étude et cartographie des formes du paysage. Lot 4 I", en G. Chouquer, F. Gateau y R. González Villaescusa, TGV LN 5 "Méditerranée". Étude des formes du paysage par carto- et photo-interprétation. Départements du Gard et de I'Hérault. Lots 22, 41 et 42, Tours, pp. 81 $|4|$.

FAVORY, F. 1996. "Morphologie agraire isocline avec une limitation romaine. Acquis et problèmes", en G. Chouquer, (ed.) Les Formes du Paysage. Tome 2- Archéologie des parcellaires, París, pp. 193-200.

FAVORY, F. 1997. "Retour critique sur les centuriations du Languedoc oriental, leur existence et leur datation", dans CHOUQUER, G. (ed.) Les Formes du Paysage. Tome 3- L'analyse des systèmes spatiaux, París, pp. 96-I26.

FAVORY, F.; PARODI, A.; POUPET, P.; RAYNAUD, C. 1994. "Lunel-Viel et son territoire", en Les campagnes de la France méditerranéenne dans l'Antiquité et le haut Moyen Age. Études microrégionales, París, pp. 163-245.

FAVORY, F.; GIRARDOT, J.j; ZANNIER, M.P. 1995. "La perception des sols et des plantes chez les agronomes romains", en S.E. van der LEEUW (ed.), Understanding the natural and anthropogenic causes of soil degradation in the Mediterranean basin. Volume 3: Dégradation et impact humain dans la moyenne et basse vallée du Rhône dans l'Antiquité (Part II). (Ejemplar dactilografiado).

FICHES, J.L;; GONZÁLEZ VILLAESCUSA, R. 1997. "Analyse morphologique et limites de perticae. Le cadastre $A$
d'Orange et le territoire de la cité de Nîmes", Les formes des paysages. Tome 3 L'analyse des systèmes spatiaux, G. Chouquer (dir.), París, pp. 127-134.

FRONTINO. 1967. "De limitibus", en F. Blume, K. Lachmann, A. Rudorff, Die Schririften der römischen Feldmesser, 2 vol., Berlín 1848; reed. Hildesheim 1967, pp. 27-33.

GAFFNEY, V.; STANCIC, Z. 1991. GIS approaches to regional analysis: a case study of the island of Hvar, Znanstveni institut Filozofske fakultete, Ljubljana.

GONZÁLEZ VILLAESCUSA, R. 1996a. "Centuriations, alquerías et pueblas. Elements pour la compréhension du paysage valencien", Les formes des paysages. 2. Archéologie des parcellaires, G. Chouquer (dir.), París, pp. I55166.

GONZÁLEZ VILLAESCUSA, R. 1997. Le rôle de la création parcellaire dans la dynamique des paysages: Secteur nîmois. Document Final de Synthèse, 1997 (inédito).

GONZÁLEZ VILLAESCUSA, R;; KIRCHNER, H. 1997. "La construcció d'un espai agrari andalusí al hawz de la madina de Yabisa. Anàlisi morfològica, documental y arqueològica del Pla de Vila", en M. Barceló (coord.), El curs de les aigües. Treballs sobre el pagesos de Yâbisa (290-633 H-902-1235 dC), Consell Insular d'Eivissa i Formentera, Eivissa, pp. 65-96.

GONZÁLEZ VILLAESCUSA, R. 2000. "Aportación al estudio de los paisajes agrarios de la Edetania. Algunas consideraciones sobre la agricultura ibérica", Scrpta in honorem E. Llobregat, Alicante, 2000.

GUY, M. 1993. "Les orientations des parcellaires quadri"lés", Revue Archéologique de Narbonnaise, 26, pp. 57-68.

GUY, M. 1995. "Cadastres en bandes de Métaponte à Agde. Questions et méthodes", en Sur les pas des Grecs en Occident, Collection Études Massaliètes, 4, pp. 427-444.

GUY, M. 1996. "Géométrie des parcellaires réguliers: le problème des dimensions", en G. Chouquer (ed.) Les Formes du Paysage. Tome 2- Archéologie des parcellaires, París, pp. 180-192.

MADRY, S.L.H.; CRUMLEY, C.L. 1991. An application of remote sensing and GIS in a regional archaeological settlement pattern analysis: the Arroux River valley, Burgundy, France, en ALLEN et alii, pp. 364-380.

MALUQUER, J. 1947-1948. "Una necrópolis romana en el fondo del embalse de San Antoni, Lérida." Empúries, IX-X, pp. 293-295.

MONTEIL, M. 1993. "Les morphogènes", en M. Monteil (dir.), Les fouilles de la Z.A.C. des Halles à Nîmes (Gard), Nîmes, pp. 4l-42.

PARCERISAS, J.; PARPAL, A.; REYES, T.; SÁNCHEZ, J. 1994. Inventari del Patrimoni arqueològic, fitxes d'Inventari de la Generalitat de Catalunya.

PARODI, A. 1992. La plaine du Languedoc oriental au haut Moyen Age (du IVe à la fin du Xie siècle): Textes et archéologie de l'espace rural, Tesis de doctorado, Universidad de París I-Panteon Sorbonne, (3 vols.), París. 
PEÑA, M. 1983. "La Conca de Tremp i sierras prepirenáicas comprendidas entre los ríos Segre i Ribera Ribagorçana -estudio geomorfológico-", Institut d'Estudis llerdencs, Lleida.

PONS, J. 1994. Territori i societat romana a Catalunya. Dels inicis al Baix Imperi, Barcelona

POUPET, P. 1993. "Un parcellaire en terrasses", en MONTEIL, M. (dir.), Les fouilles de la Z.A.C. des Halles à Nîmes (Gard), Nîmes, pp. 42-49.

PRAMA, PAYÀ, X.; PUIG, F.; REYES, T. 1994. "Primeres datacions dels nivells fundacionals d'Aeso", Revista d'Arqueologia de Ponent, 4, pp. |5|-172.

ROORDA, I.M.; WIEMER, R. 1992. The ARCHIS project: Towards a new national archaeological record in The Netherlands, a G. Lock, J. Moffet (eds.), Computer applications and quantitative methods in archaeology 1991, BAR International Series S577, Oxford, pp. I17-122.

REYES, T. 1991. Aproximació al poblament Romà a les rodalies d'Aeso: un assaig metodològic, Tesis de licenciatura, Universidad de Lleida (inédito).

ROTH CONGÈS, A. 1996. "Modalités pratiques d'implantation des cadastres romains: quelques aspects", Mélan- ges de l'École Antique de Rome et Athènes, p. 108, pp. 299-422.

SAUVAGE, L. 1996-1997. "Voie fossile et recherche de structures agraires. Garons, Reboul. DFS de diagnostic archéologique", AFAN-Coordination Artère du Midi, Gaz de France (inédito).

SHENNAN, S. 1990. Quantifying Archaeology. Edinburgh University Press. Edinburgh.

SMITH, N. 1995. Towards a study of ancient Greek landscapes: the Perseus GIS, a G. Lock i Z. Stancic (eds.) Archaeology and Geographical Information Systems, Taylor \& Francis, London - New York - Philadelphia, pp. 239-248.

TORTOSA, J.M. 1967. La Conca de tremp visión Geo-económica, Institut d'Estudis llerdencs, Lleida-Tremp, 1967.

VERHAGEN, P.; GLADE, J.Mc; GILI, S.; RISCH, R. 1995. Some Criteria for Modelling Socio-Economic Activities in the Bronze Age of south-east Spain, a Lock, Stancic (eds.) 1995, pp. 187-209).

V.V.A.A. 198I. El Pallars Jussà - estructura socio-econòmica i territorial del Pallars Jussà i de l'Alta Ribagorça, Caixa d'Estalvis de Catalunya, Barcelona, 1989. 


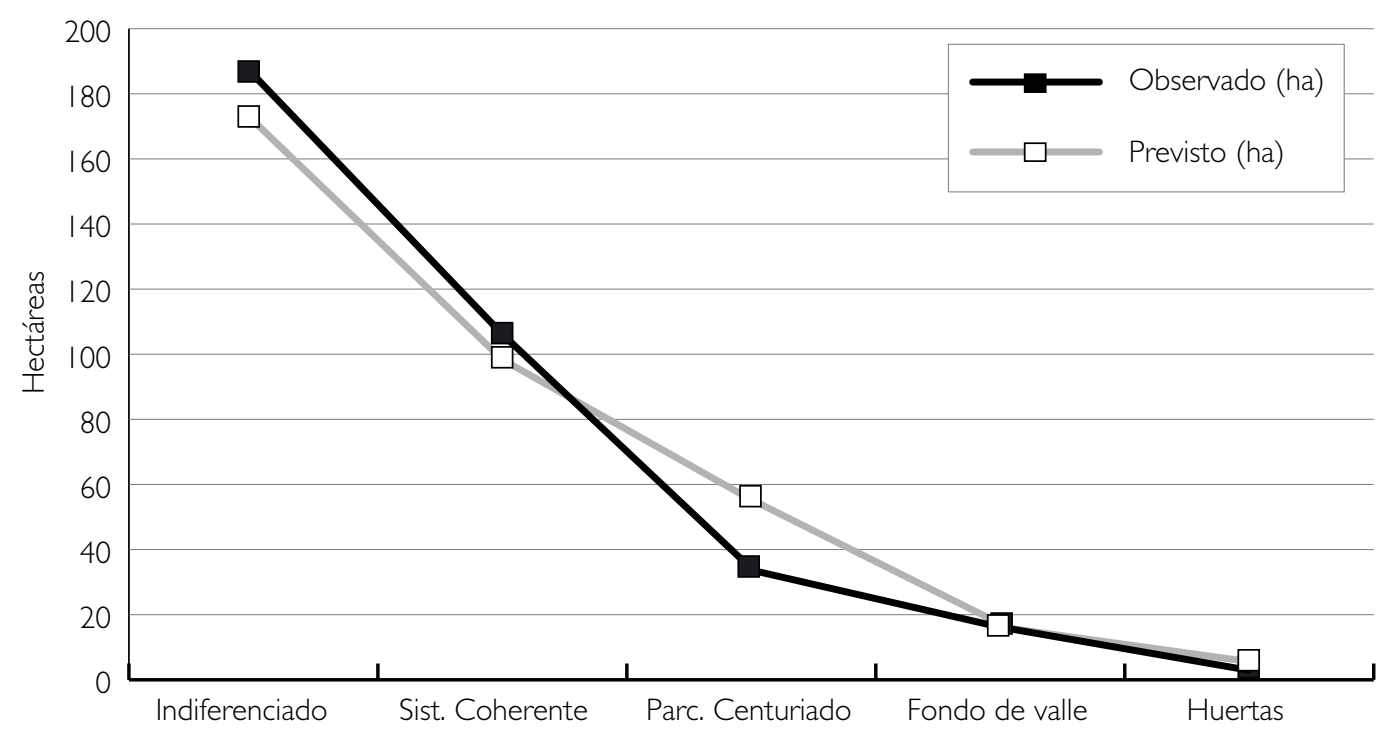

Fig. I. Parcelario y asentamientos tardo-ibéricos/republicanos (radio de 500 m)

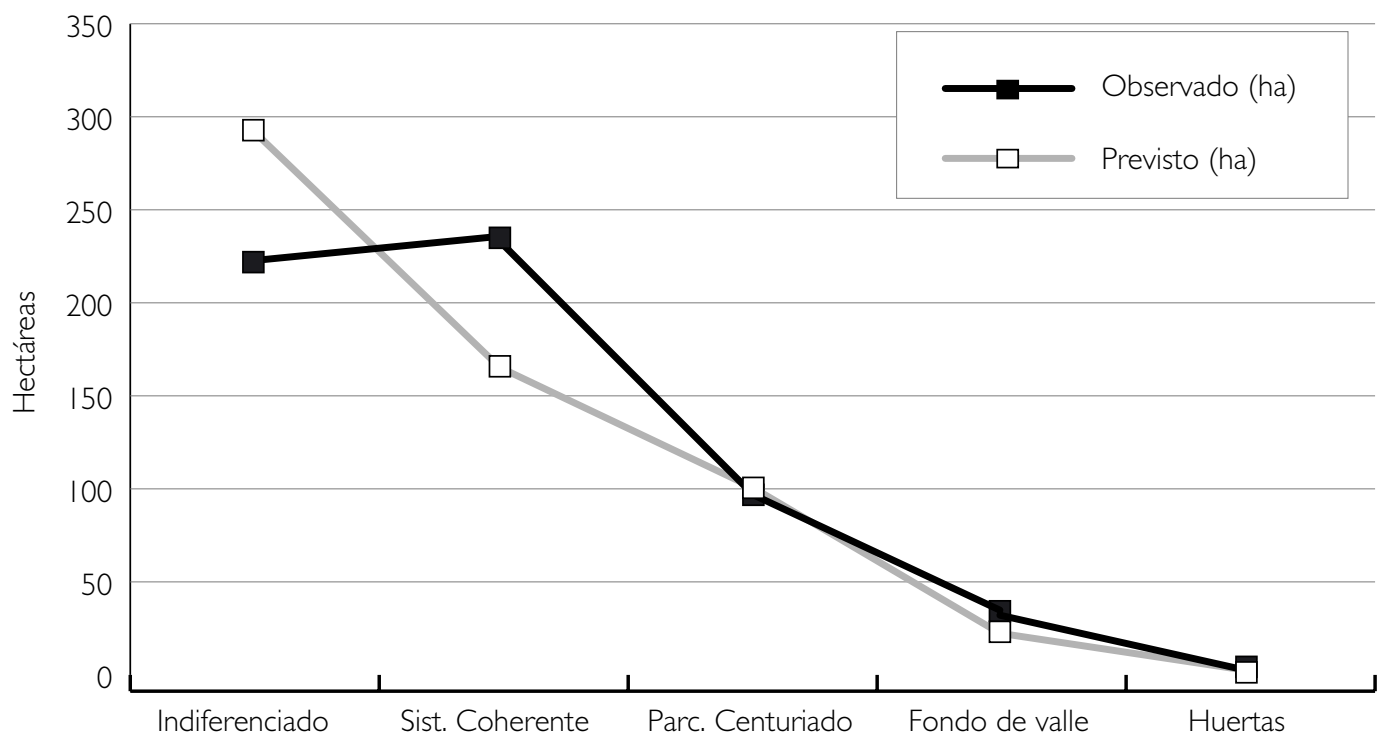

Fig. 2. Parcelario y asentamientos alto-imperiales (radio de $500 \mathrm{~m}$ ) 


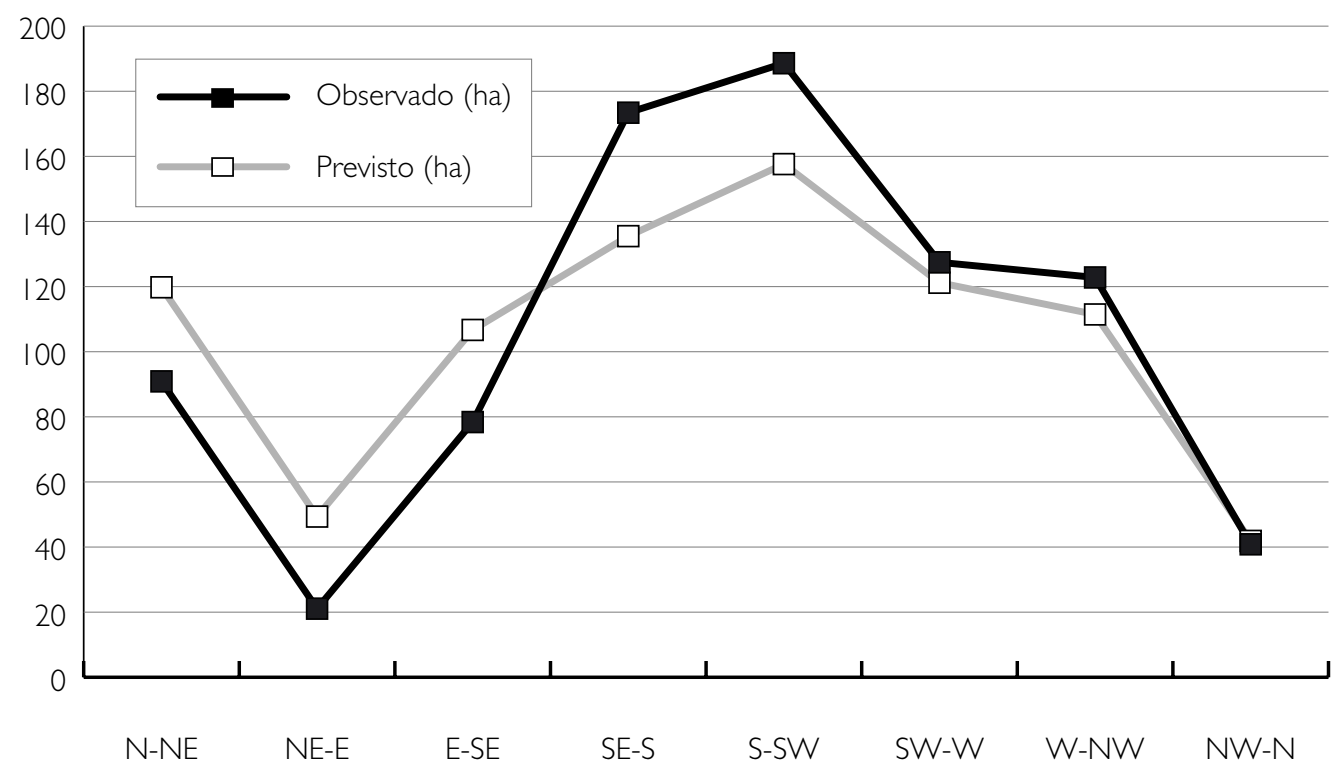

Fig. 3. Relación orientación-sistema coherente

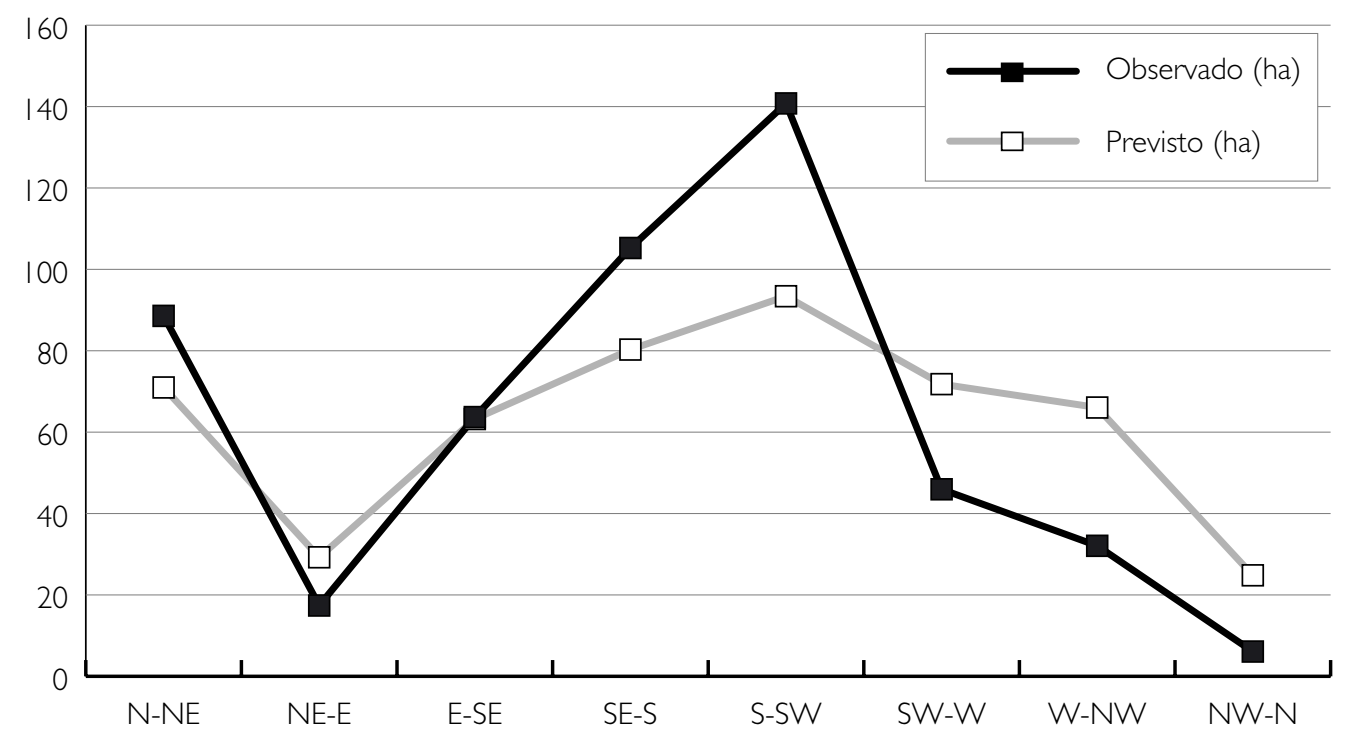

Fig. 4. Relación orientación-parcelario centuriado 


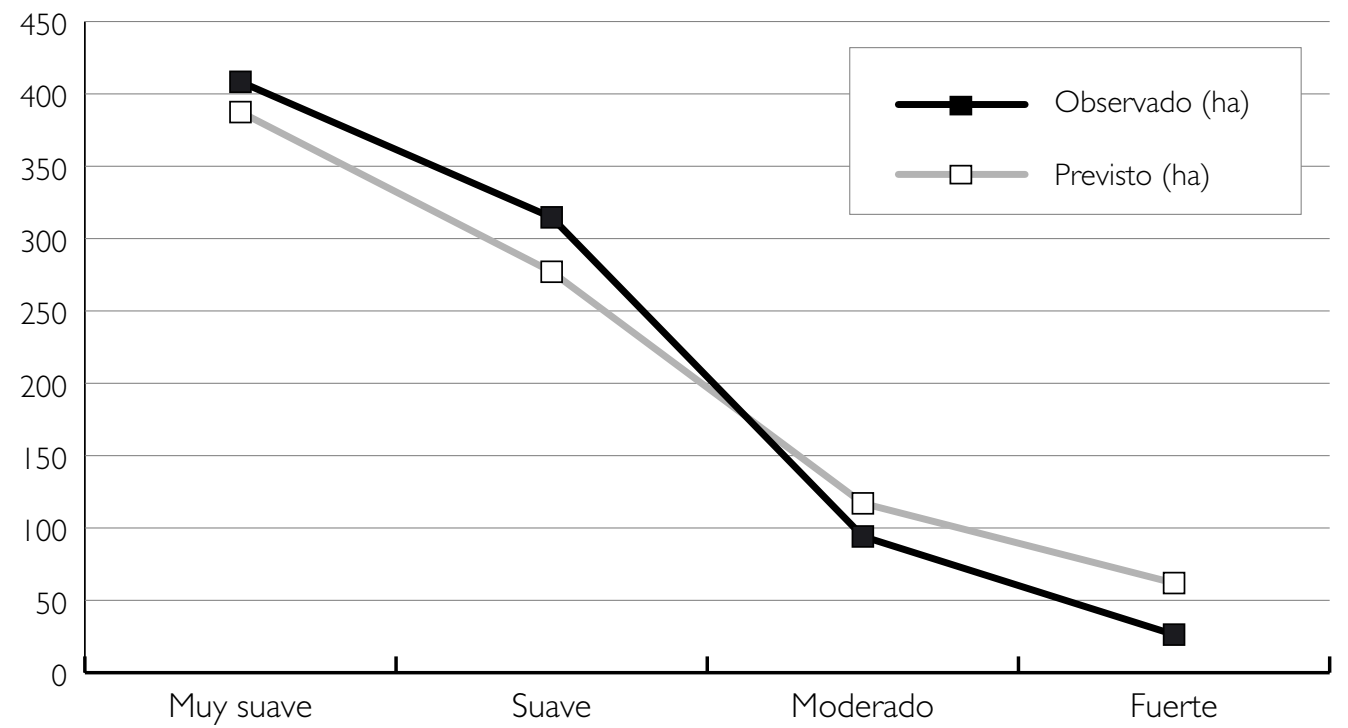

Fig. 5. Relación pendiente-sistema coherente

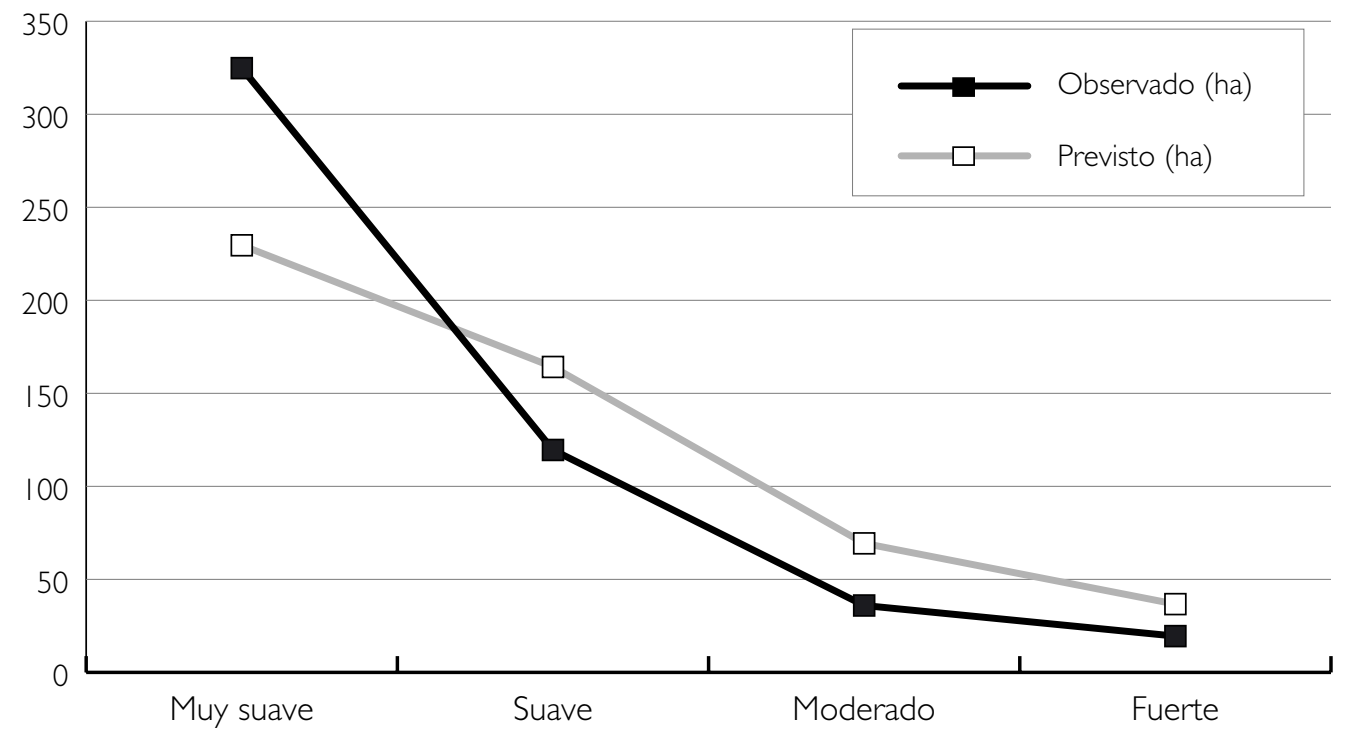

Fig. 6. Relación pendiente-parcelario centuriado 


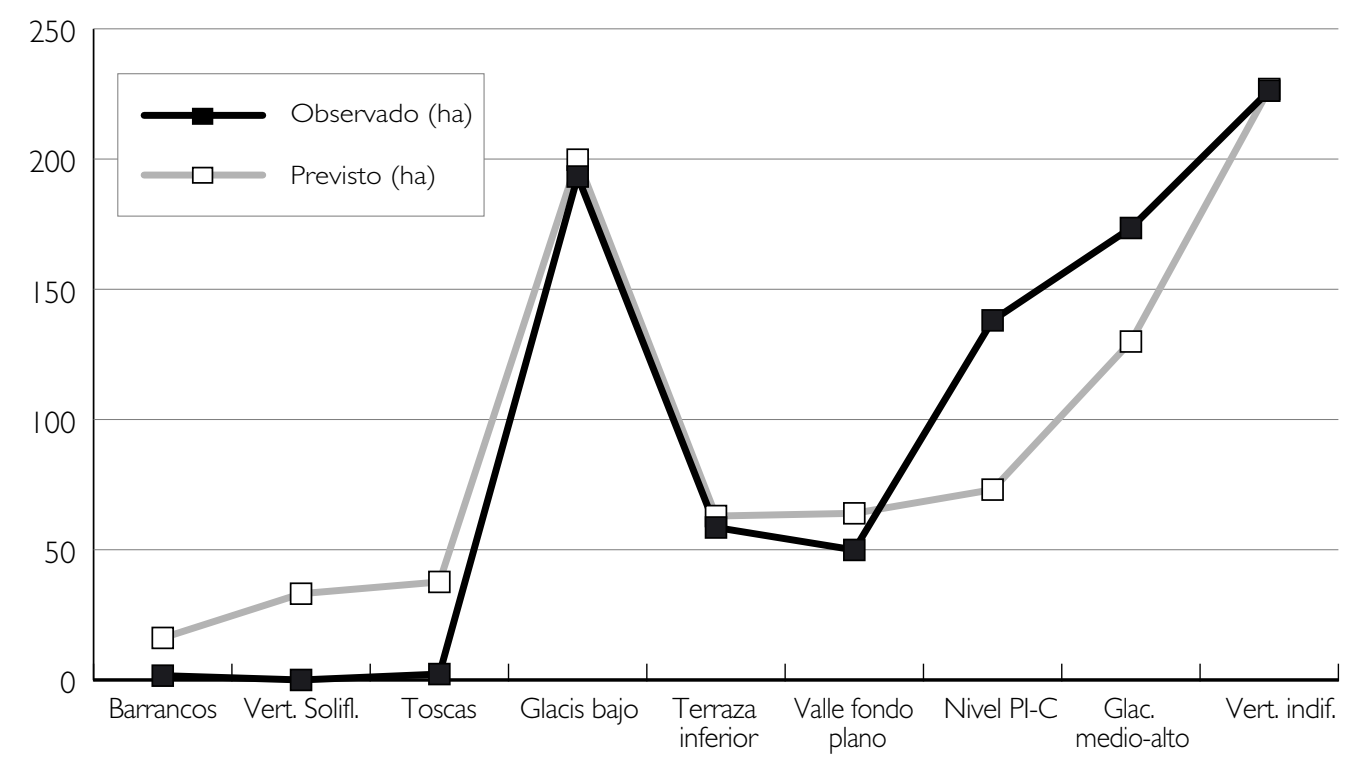

Fig. 7. Relación sistema coherente-unidades geomorfológicas

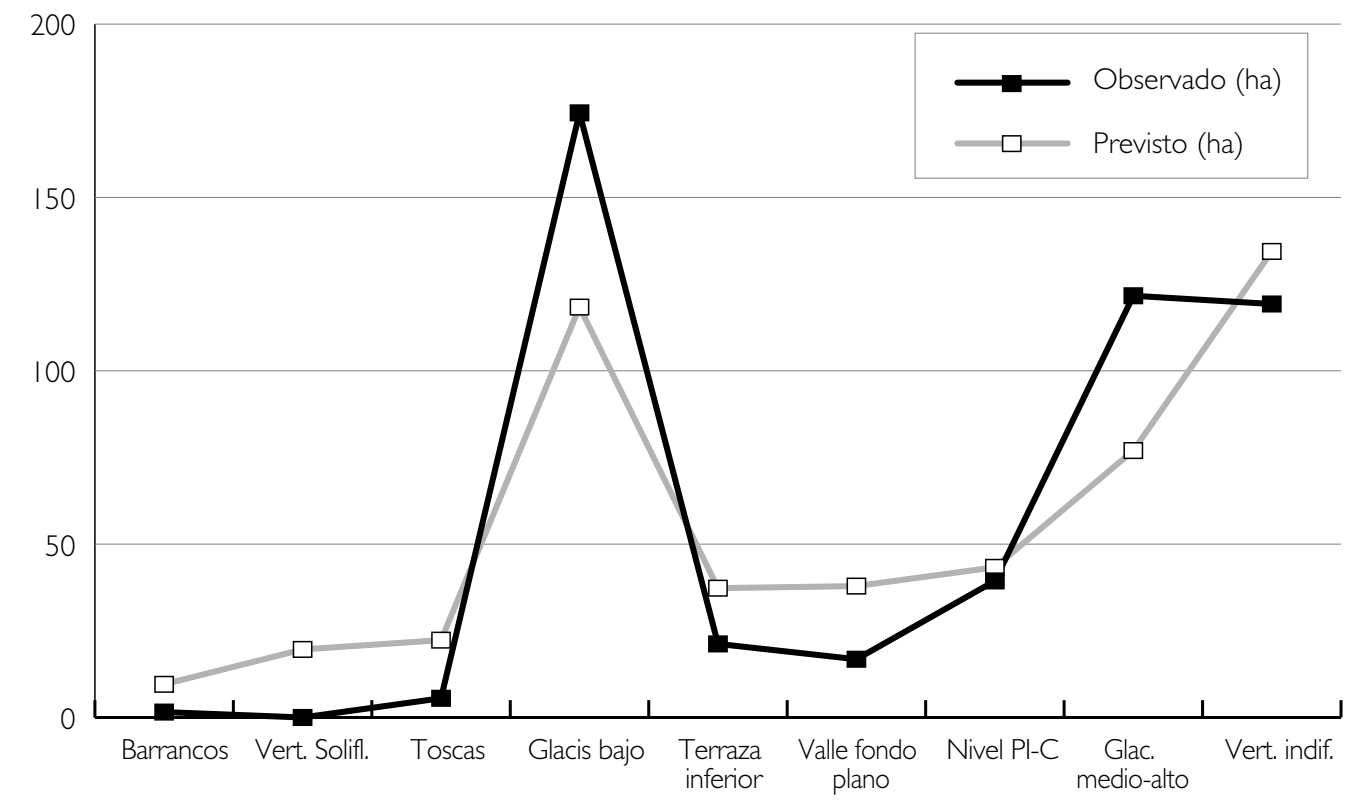

Fig. 8. Relación parcelario centuriado-unidades geomorfológicas 


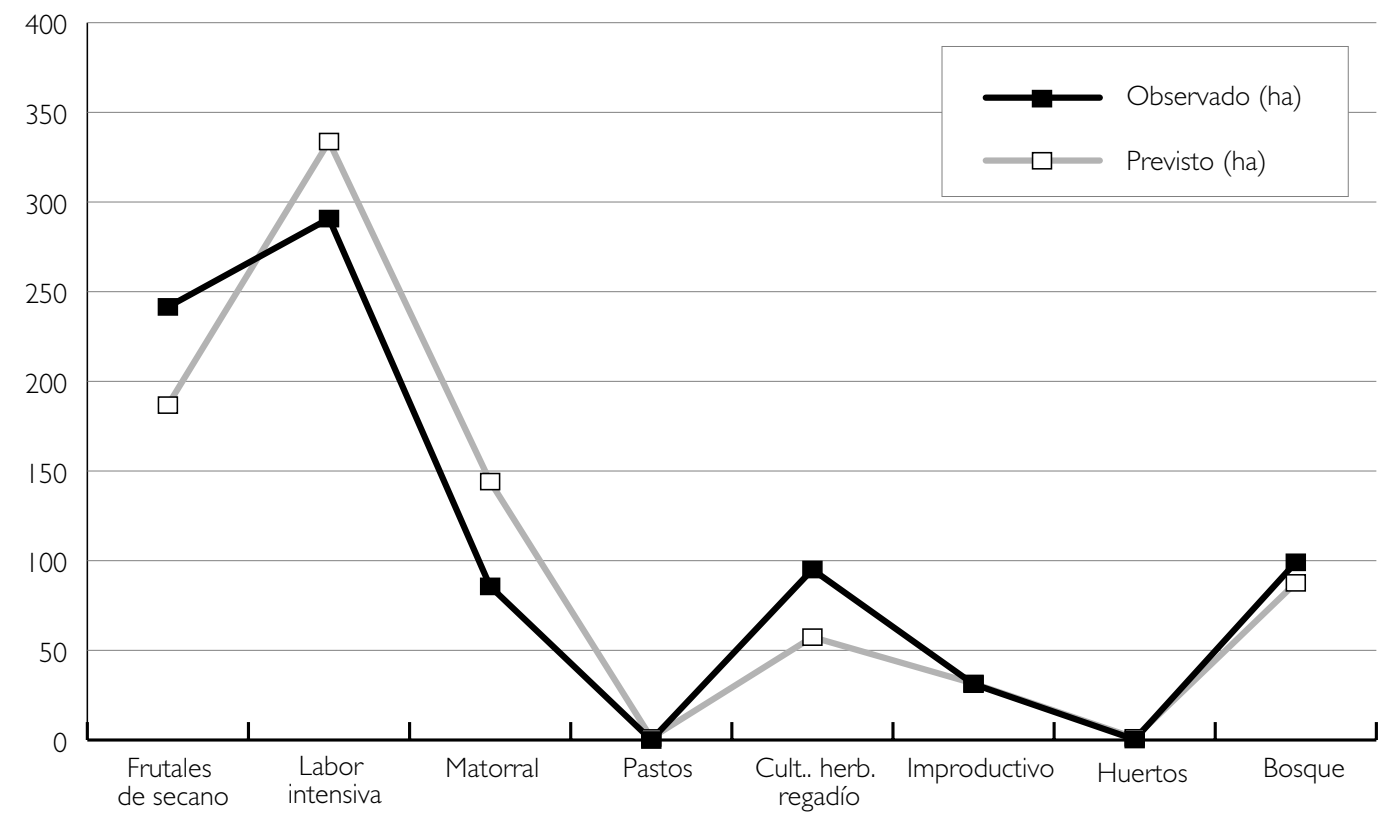

Fig. 9. Relación sistema coherente-suelos

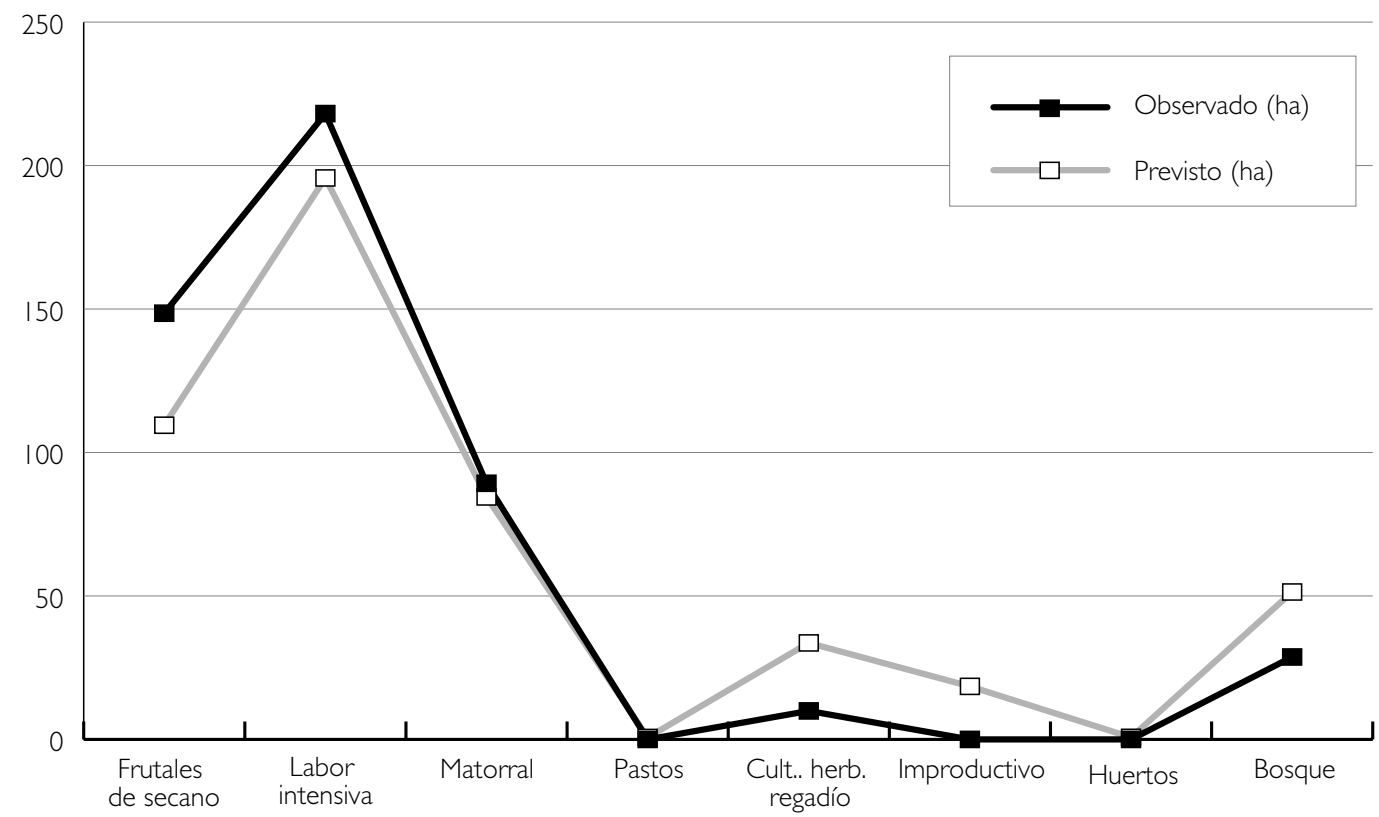

Fig. I0. Relación parcelario centuriado-suelos 


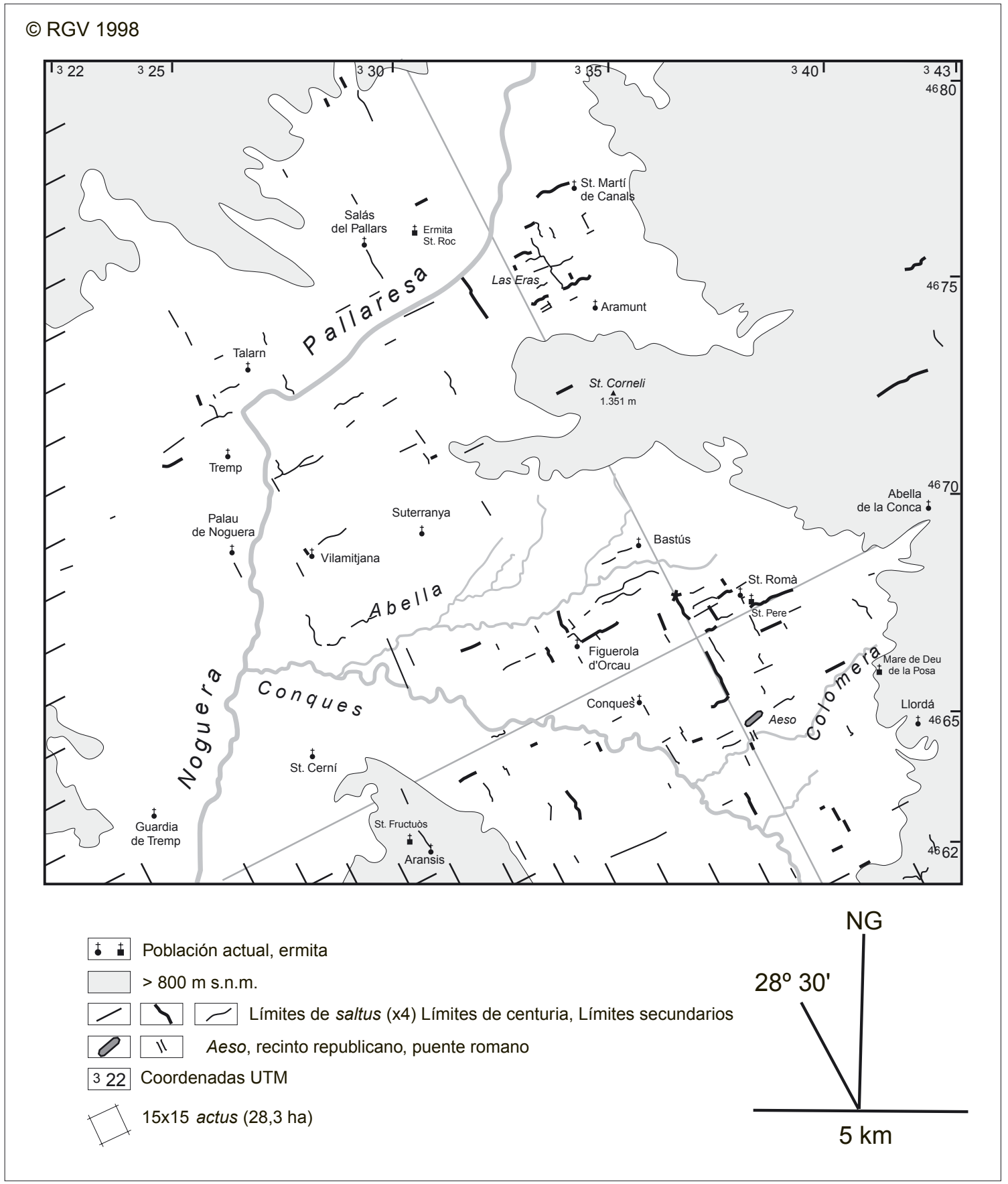

Fig. II. Dispersión de los elementos del paisaje isoclino con el parcelario centuriado en el territorio de Aeso 


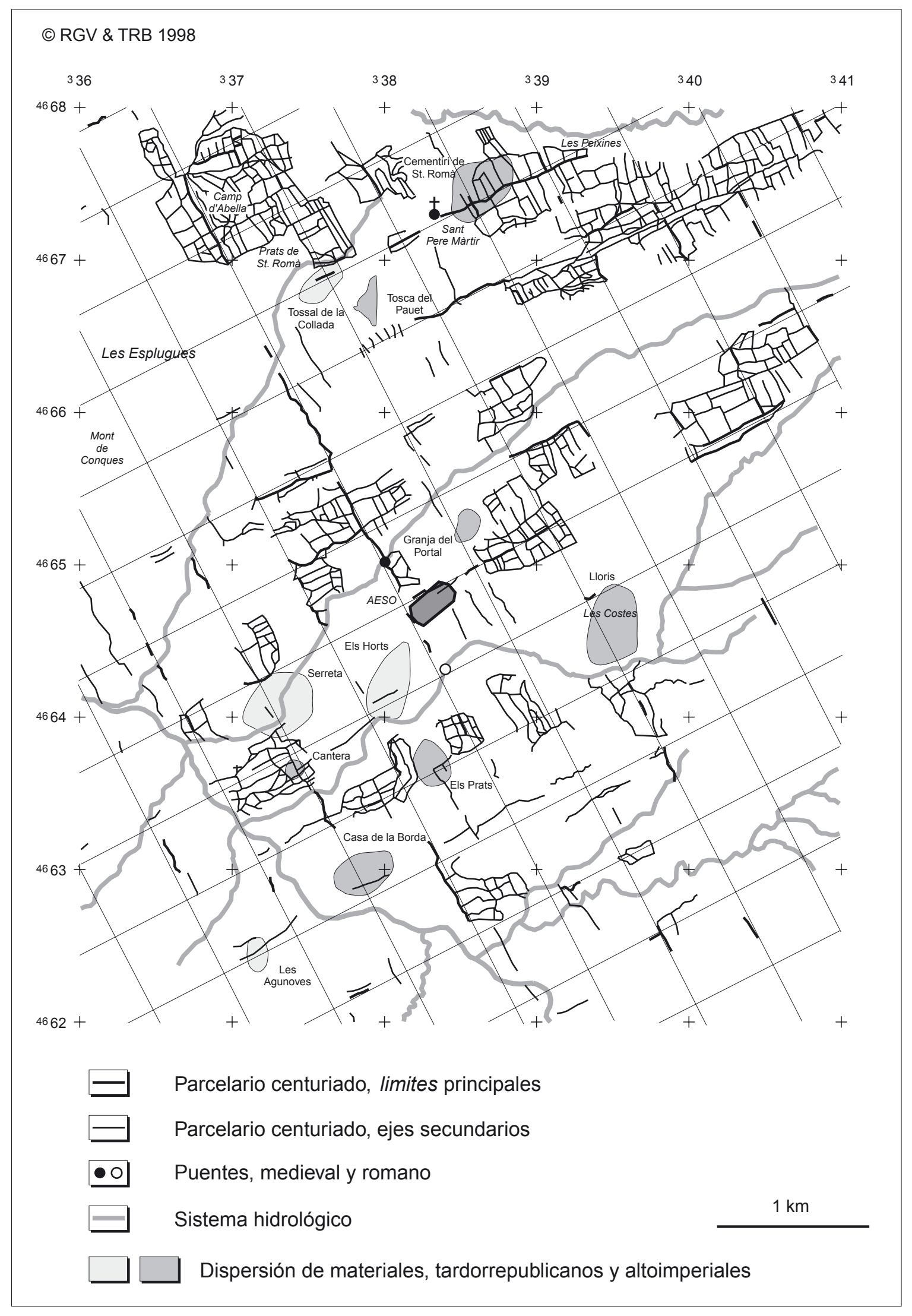

Fig. I2. Parcelario isoclino con el sistema centuriado y dispersión de yacimientos en las inmediaciones de Aeso 


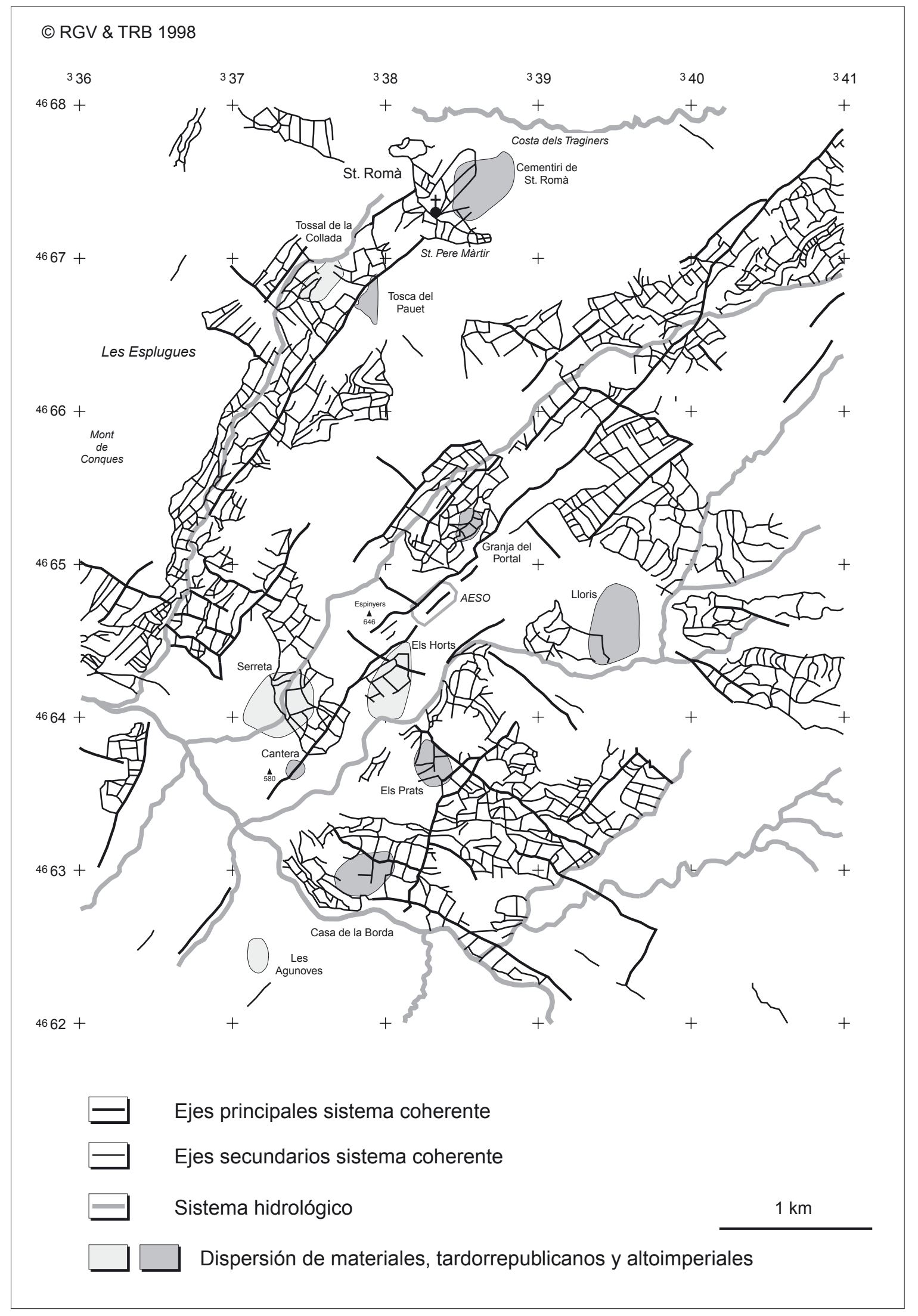

Fig. I3. Sistema coherente y dispersión de yacimientos en las inmediaciones de Aeso 


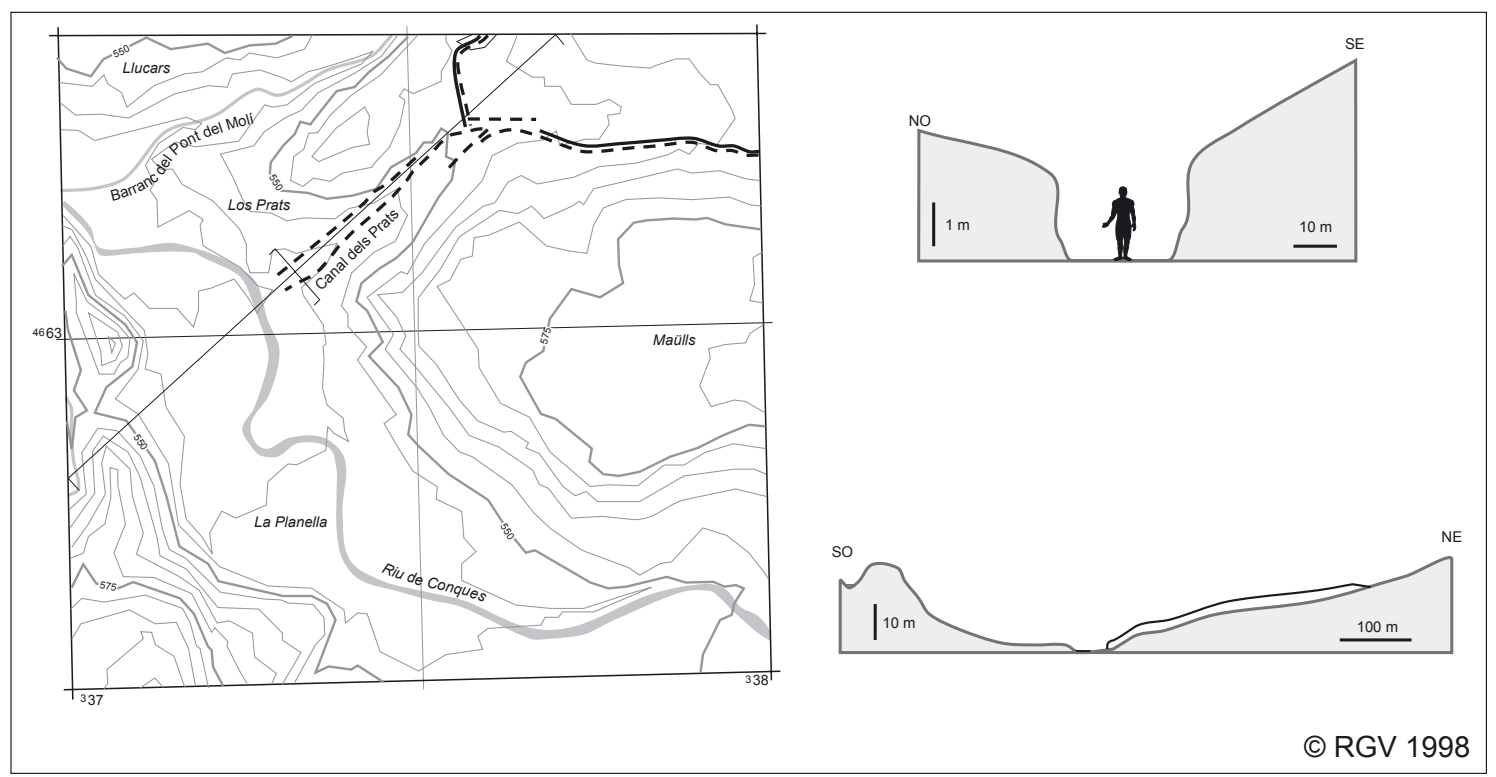

Fig. I4. Ubicación y secciones del Canal del Prats

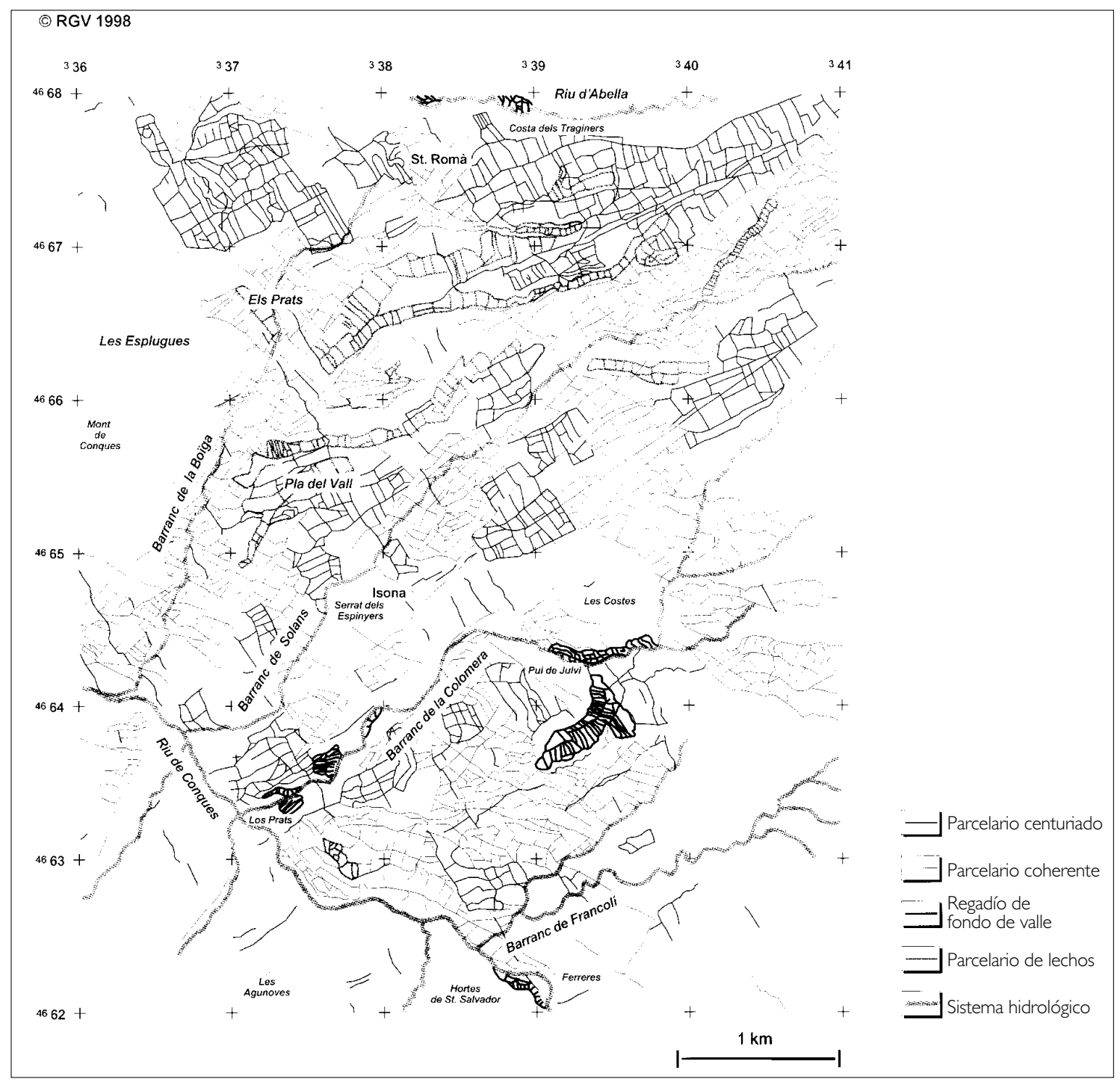

Fig. 15. Análisis de las formas agrarias en las inmediaciones de Aeso. 


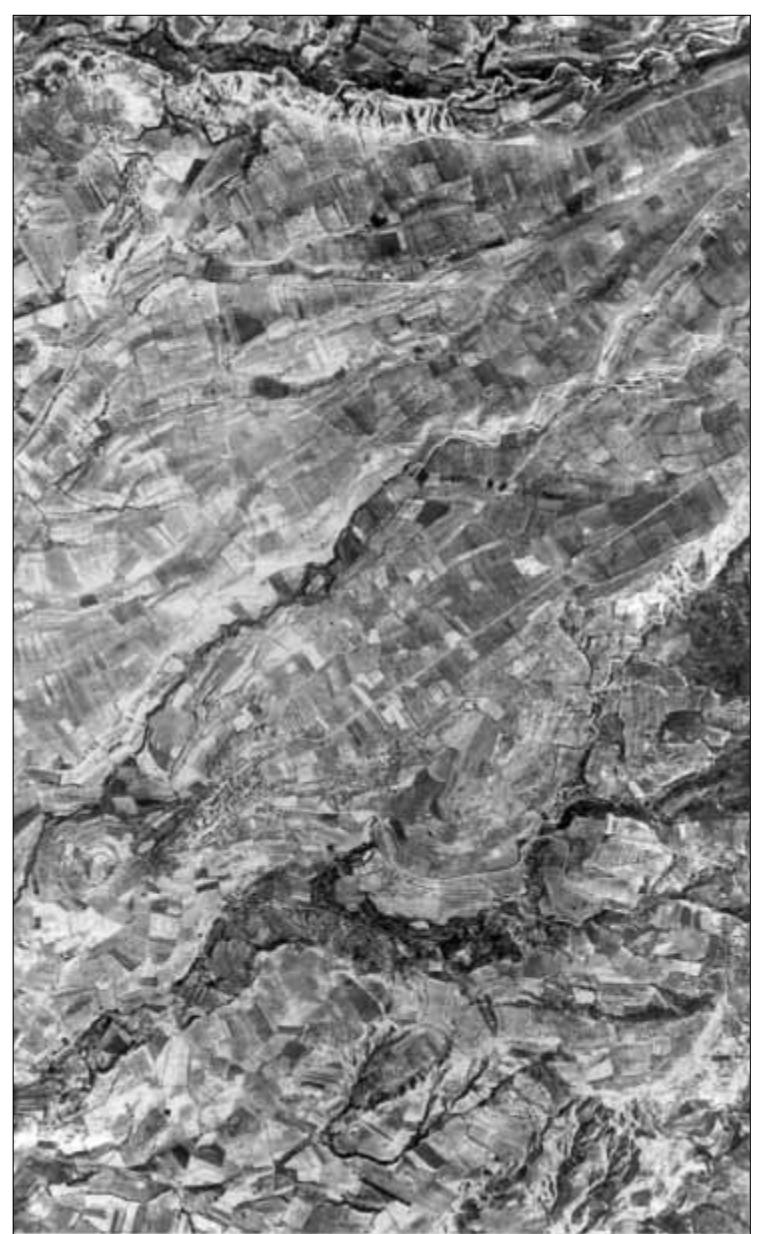

Lámina I. Aspecto parcial de la Conca Dellà al norte de Isona

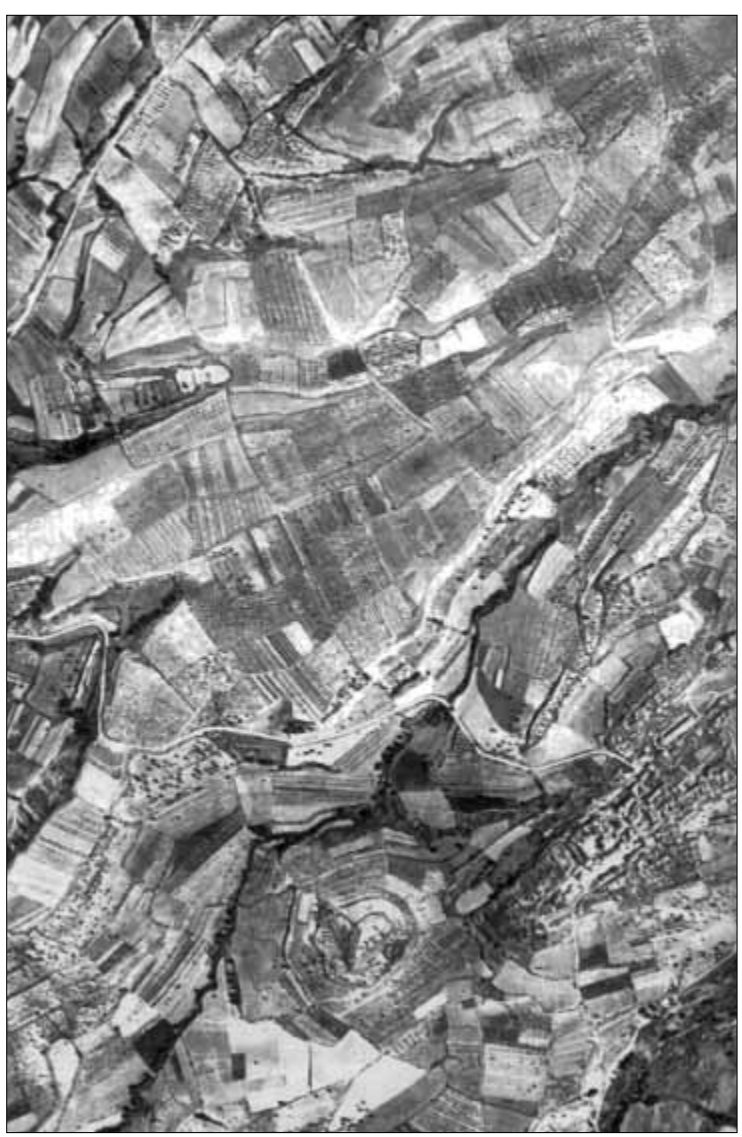

Lámina 2. Isona y el pla del Vall donde se encuentra el cardo máximo de hecho de la centuriación.

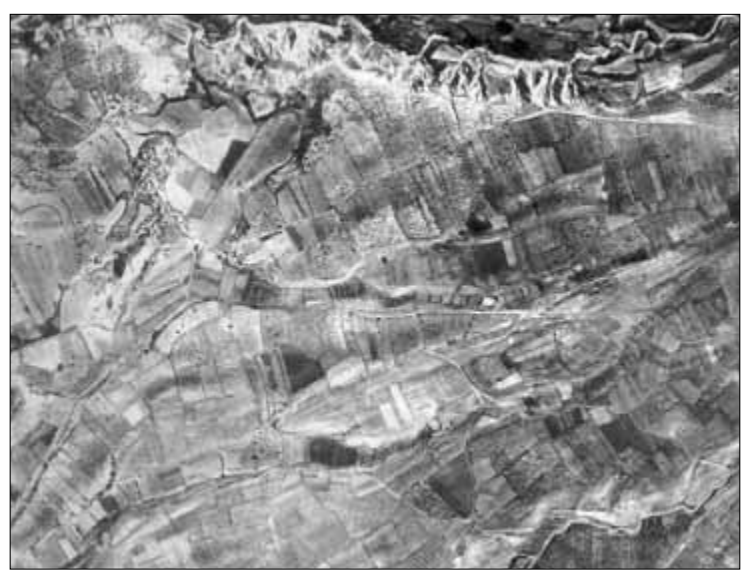

Lámina 3. Población de S. Romà d'Abella y decumanus de la villa de S. Romà.

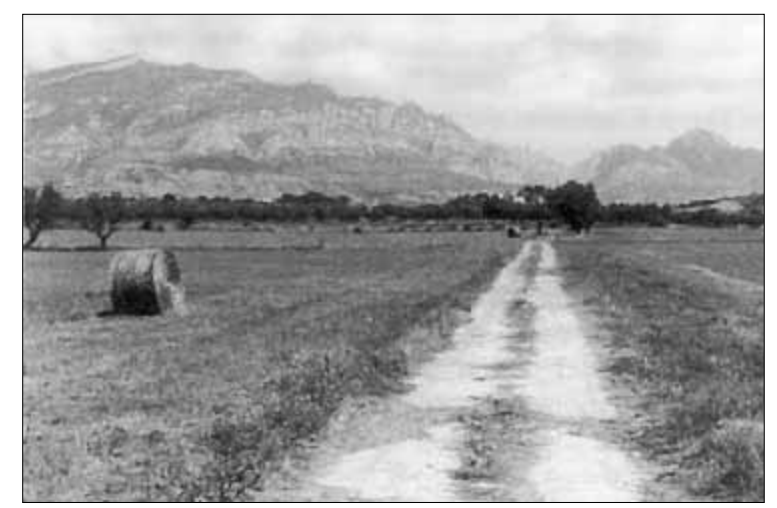

Lámina 4. Camino de les Casotes. Sant Romà d'Abella. Sigue el trazado de la antigua centuriación romana. 